多数認めます。この小体浪諸家により lysosome と云わ れていますが，現在明らかにされたと注い難く，問題 のあることころと思います。

次いで 221 例の小昌剖検例中，次の 5 例に巨細胞封入 体を認めました。

3 歳女子，白血病（肺，リンパ節，心筋）

一女子, 死産坚 (肺)

9 力月女子, 腎腫瘍 (腎)

2 力月男子，気管支脑炎 (肺，脾臟）

6 紫男子, 白血病 (顎下腺)

6 歳男子白血病例の顎下腺の巨細胞を電顕で観察した 結果，前述の成人例と同様の所見学得ました。

なお，成人の全身性巨細胞封大体症に関古当詳細は札 愰医学雑誌第 31 巻第 1 号を参照されたい.

\section{B. Mycoplasma}

莝長水谷裕迪

(関東避信病院小児科)

\section{1. マイコプラズマ・ニュモニエ肺炎の䛦} 断について

東京大学医科学研究所
中 村 昭 司
海老沢 功

\section{i. 緒 蒠}

マイコプラズマ・ニュモニエ (Mycoplasma pneumoniae : 以下 M. pn. と略記) 肺炎の診断孝臨床像加ら 下寸ことは困難である. M. pn. の分離および血清学 的方法によつて初めて診断が可能である。これらの M。 pn. 肺炎の実験室内診断法は，過去 10 年閒に絶えず進 歩を続けて来たが，まだ解決の問題が残つており， また特にわが国では一般の病院，診療施設などで日常の 検查にとり大れられるところまで来ていない.ここでは 私達が最近 4 年間に行なつて来た M. pn. 脑炎の実験室 内診断の方法とその成績を紹介し，考察を加えたいと思 う。これが，診断法の普及改良にいくらかでも役立てば 幸である。

\section{ii. M.pn。の分離法}

M. pn. の分離用培地として発育嫍楖，寒天培地，液 体培地，寒天液体二相培地などがあるが，私達は，寒天 培地法主亡して採用している。

方法は Chanock ら (1962a) の報告したものとほぼ同 ビである.すなるち, trypticase soy broth に0.5\% ウ
シ・アルブミンを加えた液で患者にうがいをさせこれを 分離材料とし, これを PPLO 寒天培地に接種した. 分 離材料として咽頭ぬぐい液を用いている報告もあるが, うが、のできない小児ではこの方が便利である，成人で は，らがいの方が行ない易いが，どちらの材料がより漓 い検出率が得られるが検討していない，寒天培地の成 分は, Difco PPLO agar 7 容, 非働化しない馬血清 2 容, 酵母エキス 1 容，䣷酸タリウム $0.5 \mathrm{mg} / \mathrm{ml}$, ペニシリン 500 単位 $/ \mathrm{ml}$ である。この寒天培地㨁径 $4 \mathrm{~cm}$ のシャ ーレに作り，密閉した罐に入れて $4^{\circ} \mathrm{C}$ に保存し， 2 週 閒以内に使用している。

らがい液怔採後，できるだけ早く培地に接種するよ らにした。 やむ学次場合は， $-20^{\circ} \mathrm{C}$ に保存して 1 〜 2 日後に接種したが,このようなものは少数である。

接種した培地俚，36 $37^{\circ} \mathrm{C}$ に好気性に培養し，約 1 カ月間，顕微鏡下でコロニー出現の有無孛観察した。

コロニーが斥つかつた場合は，ふつう2枚のシヤーレ を使つているらちの1枚で同定を行なつた。私達の経験 では 2 枚のうちの1枚だけにコロニーが出た例はなかつ た. 同定には，第1にコロニーの外観からすぐにM.pn. ではないと判定できるものがあり，これらのものは，次 の同定手順をふまずに除外することができた.このため には検者が，M. pn. のコロニーの特微をよく知つてい. る必要がある、それには，実際に数多くのコロニーを見 るのが一番よいが，ここに要点を示すと：1）発育が比 較的遅い，通常初代分離時に法7日以上加加る。2）二 ロニーを形成している顆粒状の構造が細く密であるため 硬い，つやのある感じを受ける，3）中央部にニップル を形成しない場合があり、ニップルを形成する場合でも 比較的境界不鮮明な感じがある，4）大きさ注，あまり 大きくはならない，すなわち最大值径 100 ミクロンとみ てよく，それ以上大きくなるものは M. pn. でない可能 性が多い。

同定手鿓の第 2 は，コロニーの外観上 M. pn. らしい と考えられたものについて, 動物赤血球の吸着試験また は溶血試験を行なつた。この方法はSomerson ら (1963) DelGuidice ら (1964) の考案によるもので，とくに吸着 試験の方壮，簡便で信頼度も高くよい方法である。ニワ トリまた㳉モルモットの3\%血球液をコロニーの上にの 巳約 15 分後に生理的食塩水で軽く洗い流して 検鏡する とコロニーの周囲に血球が吸着されているのが観察され る.

同定手順の第 3 は，グルコースを醪酵する性質がある かどうかの検查で，これは液体培地の中にグルコースを $1 \%$ に，フェノールレッドを $0.002 \%$ に加えておけば, 色の変化で醱酵能の有無を知ることができる、液体培地 
の成分は, 前記寒天培地の成分中の PPLO agar の代り に PPLO broth を用いたものである。

最終的な同定法は，血清学的方法である。これにはい ろいるな方法が考案されているが，私達は初めは，荒井 ら (1964)の寒天培地を用いて行なう中和試験法を採用し 途中からヒトの回復期血清（䖝光抗体法による抗 M.pn. 抗体洒が 1:256のものを 64 倍希釈で使用) を用いる螢 光抗体染色法に上つた.

\section{iii. 分離成績}

115 名の肺炎患者についての 分離成續は表 1 のごとく 血清学的診断で M. pn．肺炎と証明された 25 症例中， 17 例永ら M. pn. が分離され，M. pn. 以外のマイコプ ラズマはわすかか 2 株しか分離されていない。しかもこの 2 株とも, 上記 17 例中の 2 例から M. pn. と重複して 分離されたものである。

表 1 分離成績 (1) 血清診断との対比

\begin{tabular}{|c|c|c|c|c|}
\hline & 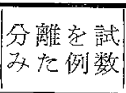 & $\begin{array}{l}\text { M. pn. } \\
\text { 分離 }\end{array}$ & 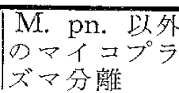 & $\begin{array}{l}\text { 分離 } \\
\text { 陰性 }\end{array}$ \\
\hline 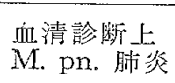 & $\begin{array}{c}25 \\
(100 \%)\end{array}$ & $17(68 \%)$ & $\begin{array}{l}\% \\
2(8 \%)\end{array}$ & $8(32 \%)$ \\
\hline $\begin{array}{l}\text { Im 清診断上 } \\
\text { 非 M. pn. } \\
\text { 肺炎 }\end{array}$ & $\begin{array}{c}90 \\
(100 \%)\end{array}$ & $1(1 \%)$ & $\begin{array}{l}※ ※ \\
24(27 \%)\end{array}$ & $66(73 \%)$ \\
\hline
\end{tabular}

（註） 1) M. pn.‥マイコプラズマ・ニュモ二エ

2)※印の 2 例，抢よび※※印中の 1 例は M. pn. 亡雨方学同時飞分離.

3）分離材料採取前に抗生剂を使用していない もののみを集計した。

血清診断上，M.pn. 肺炎でなかつた 60 症例から注 24 例から 24 株の M. pn. 以外のマイコプラズマが分離さ れた. M.pn. 初ずか 1 株が，上記 24 例中の1例から M. pn. 以外のマイコプラズマと同時に分離されたのみ である。

この成績から，肺炎患者方ら M. pn. 驾分離された場
合は，血清学的にも M. pn. 肺炎と晾断される率は極め て高く，分離だけでも M. pn. 肺炎と診断してほぼ間違 いないといえる。しかし，M. pn. 分離陰性の瑒合は， 血清学的診断を待たなけれ壮何さもいえない.

M. pn. 以外のマイユプラズマが果して肺炎の病原し して関与しているのかどうかは今後に残された課題であ る.

分離株の同定法に関しては，寒天培地上のコロニーの 外観からだ汀でもかなりよく、M. pn. 在見分けることが できること，さらにこれを確諗するには，動物（二ワト リまたはモルモット）の血球を用いた吸着検査と，グル コースの醱酵能検査を行なうのが簡便でしかも確実であ ることを知つた。

らがマ液を採取した病日と分離成續との関係は図 1 の ごレくであり，発病後早い時期の方分分離率はよいが， 遅くなつてもな执なり分離できる。

うがい液を培地に接種してからコロニー出現までの期 閒は，表 2 ごとくで女る。多くのものでは7日から14 日の間にコロニー出現を多るが，15日以後に出るものも あつた。最す遅いるのは24日であつた。

表 2 分離成績 (3) らがい液接種後コロニー 出現まての日数の分布

\begin{tabular}{c|c|c}
\hline 日 数 & 例 数 & 率 \\
\hline $7 \sim 10$ & 5 & $33 \%$ \\
$11 \sim 14$ & 7 & $47 \%$ \\
$15 \sim 18$ & 2 & $13 \%$ \\
$19 \sim 24$ & 1 & $7 \%$ \\
\hline 計 & 15 & $100 \%$
\end{tabular}

1つのシヤーレ当りに出るコロニー数は表 3 のごとく で，コロニー数が 5 個以内のものが $40 \%$ も亦り，顕微 鏡で観察する場合に見落し易けので注意を要する。寒天

図 1 分離成績 (2) うがい液採取病日上分離成續の関係

(血清診断上マイコプラズマ・ニュモニエ肺炎例について集計)

\begin{tabular}{|c|c|c|c|c|c|c|c|c|c|c|c|c|c|}
\hline うがい液採取病日 & 1 & 3 & 5 & 7 & 9 & 11 & 13 & 15 & 17 & 19 & 21 & 23 & 25 \\
\hline 分離の有無 & $\begin{array}{r}\oplus \oplus \\
\oplus \\
\oplus\end{array}$ & & $\begin{array}{c}\Theta \oplus \oplus \\
\oplus \oplus \\
\oplus \Theta \\
\Theta\end{array}$ & $\begin{array}{l}\oplus \oplus \\
\ominus\end{array}$ & $\begin{array}{l}\oplus \\
\ominus\end{array}$ & $\begin{array}{l}\oplus \oplus \\
\oplus\end{array}$ & $\Theta \Theta$ & & $\ominus$ & $\oplus$ & & $\Theta$ & \\
\hline
\end{tabular}

（註）1）の印一つ加一例

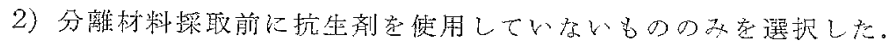


表 3 分離成績 (4) 分離時出現したシャーレ 当りのコロ=一数の分布

\begin{tabular}{c|c|c}
\hline$\geq a 二-$ 数 & 例 数 & 率 \\
\hline $2 \sim 5$ & 6 & $40 \%$ \\
$6 \sim 10$ & 2 & $13 \%$ \\
$11 \sim 50$ & 2 & $13 \%$ \\
$51 \sim 100$ & 4 & $27 \%$ \\
$>100$ & 1 & $7 \%$ \\
\hline 計 & 15 & $100 \%$
\end{tabular}

培地にグルコースとフェノールレッドを加えて色の変化 でコロニー出現を知るなどのて夫が望まれる。

\section{iv。 血清学的診断法とくに補体結合反応の方法}

M. pn. の抗体証明に使われる血清反忘㳉，現在数種 類考案されている。

私達は，研究初期の頃は，螢光抗体法を用いていたが 補体結合反忘 $(\mathrm{CF})$ 用の抗原作製が可能になつてからは 主としてこれを用いている。

抗原の作製法は，原理的には Chanock 5 (1962b) の 報告のものと同じであるが，一部の点で改良を試みた。 すなわち，液体培地にグルコースとフェノールレッドを 加えて, これに M. pn. を接種し, 振盪培養を行なう. この時, 比較的大量の人工培地になれた M. pn. (コ口 ニー形成単位で現わして $10^{4} \sim 10^{6} / \mathrm{ml}$ ) を接種すること と，振盪を行ならことが，よい抗原を得るためのコツで あると考えている. $\mathrm{pH}$ が 7.8 から出発して，6.8kな つたところで液にフェノール索 $0.5 \%$ に加えて $37^{\circ} \mathrm{C}$ に 4 日間怙き，これを $56^{\circ} \mathrm{C} ， 30$ 分間で非働化してから， 10,000G. 30 分間遠心し, その沈渣をもとの液の $1 / 20$ 量 の veronal buffered saline に雨浮遊させる.この方法 により，32ないし 64 程度の抗原㑑のものが得られ，抗 補体作用は全く歹らない。

CF の術式法, 抗原 3 単位, 補体 2 充単位学用いた Kolmer の変法で行なつた. 内径 $8 \mathrm{~mm}$ の小試験管で血 清 $0.1 \mathrm{ml}$, 抗原 $0.1 \mathrm{ml}$, 補体 $0.2 \mathrm{ml}$, 感作血球 $0.2 \mathrm{ml}$ の 量学用いた。

\section{v。 補体結合反応の成績}

190 名の肺炎患者のベア血清儿ついて，CF 反応を行 なつた結果法次の 5 種類に分けられる（図2）。1）第 一血清加ら第二血清にかけて抗体佂が 4 倍以上上昇した もの 2）同しくく2 倍上昇したもの 3) 第一血清ですで に抗体価が高くて第二血清で不変のもの 4) 第一血清 ですでに抗体価が高くて1/2 に下降したもの 5) 第一 血清，第二血清乙も抗体佂が低いもの (図に沙省略).

これらの中，1）と5）核䉼上とくに問題がない.

2)，3），4）のグループをどう判定するかが問題と

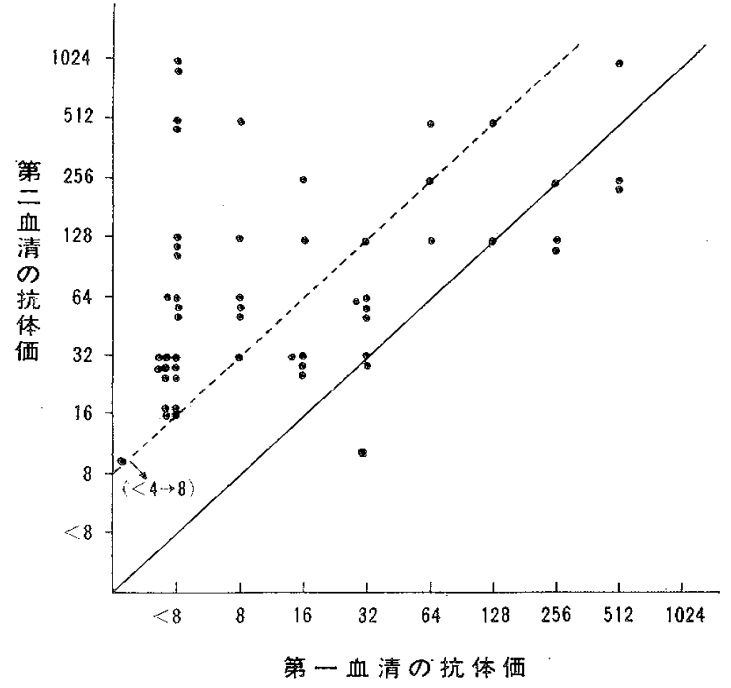

図 2 血清学的診断の成續 $<ヘ ゚ ア$ 血清のCF抗体洒 $>$.

なる。

肺炎患者汇一般に発病初期法ふつらの「か十尤」ぐらい に考えて診察を受计ない場合怔多い。また診察索受けて も医者加肺炎を疑らの壮症状が進んでからのことが多い ので肺炎といら診断がつくのはどうしても遅れがちであ る。したがつて第一採血日が遅くなりがちである。

表 4 ペア血清の CF 洒の動きと 第一採血病目との関係

\begin{tabular}{|c|c|c|c|c|}
\hline $\mathrm{CF}$ 㑑の動き & $1 \sim 7$ & $8 \sim 15$ & 5以上 & 計 \\
\hline 4 偣以上上景 & 29 & 10 & 4 & 43 \\
\hline $\begin{array}{c}2 \text { 倍上搨 } \\
\text { (第一组清 } \mathrm{CF} \text { 価 } \geqq 16 \text { ) }\end{array}$ & 1 & 8 & 1 & 10 \\
\hline 不 $\stackrel{\text { 装 }}{(\mathrm{CF}}$ 洒 $\geqq 32)$ & 0 & 3 & 3 & 6 \\
\hline $\begin{array}{c}{ }^{1 / 2} \text { K下降 } \\
\text { (第一血清 } \mathrm{CF} \text { 佂 } \geqq 32 \text { ) }\end{array}$ & 0 & 3 & 1 & 4 \\
\hline 計 & 30 & 24 & 9 & 63 \\
\hline
\end{tabular}

前述のペア血清の抗体価の働きと第一採血日の病日と の関係㐗調べると，表 4 のごとくで，第一採血日が遅く なるほど前述の 2），3），4）のグループのものが高 率となる。

宋た，ペア血清で CF 倓が 2 偣上昇孝示した 7 例につ いて，螢光抗体法により抗体価を調べると表 5 のごとく 7 例中 5 例壮有意な (4 倍以上上昇) 抗体価上景莛示し ている.またその 5 例のうち4 例は，M. pn. の分離も 陽性で文つた。

以上のデータから，CF で抗体価が 2 倍しか上昇しな 
表 $5 \mathrm{CF}$ 価 2 倍上暴例の検融

\begin{tabular}{|c|c|c|c|c|}
\hline Case No. & $\begin{array}{l}\text { Day of } \\
\text { Disease }\end{array}$ & $\mathrm{CF}$ & FA & $\begin{array}{l}\text { Isolation } \\
\text { of M. pn. }\end{array}$ \\
\hline \multirow{4}{*}{ No. 14} & 2 & 16 & 16 & \multirow[t]{4}{*}{+} \\
\hline & 39 & 32 & 128 & \\
\hline & 163 & 16 & 128 & \\
\hline & 390 & $<4$ & 8 & \\
\hline \multirow{4}{*}{ No. 35} & 11 & 32 & 32 & \multirow[t]{4}{*}{+} \\
\hline & 30 & 64 & 128 & \\
\hline & 145 & 16 & 64 & \\
\hline & 365 & $<4$ & $<8$ & \\
\hline \multirow{2}{*}{ No. 72} & 9 & 32 & 64 & \multirow[t]{2}{*}{ nt } \\
\hline & 24 & 64 & 64 & \\
\hline \multirow{2}{*}{ No. 248} & 8 & 8 & 8 & \multirow[t]{2}{*}{+} \\
\hline & 24 & 16 & 32 & \\
\hline \multirow{2}{*}{ No. 353} & 12 & 32 & 16 & \multirow[t]{2}{*}{$\mathrm{nt}$} \\
\hline & 20 & 64 & 32 & \\
\hline \multirow{2}{*}{ No. 373} & 12 & 16 & 16 & \multirow[t]{2}{*}{$\mathrm{nt}$} \\
\hline & 21 & 32 & 64 & \\
\hline \multirow{2}{*}{ No. 453} & 14 & 16 & 16 & \multirow[t]{2}{*}{+} \\
\hline & 36 & 32 & 128 & \\
\hline
\end{tabular}

nt: not tested

かつた例でも，第一採血日が発病後 1 週以上過ぎており 抗体洒がすでに 16 以上あるものは陽性にとるべきであ ると考える。抗体価が $1 / 2$ に下降七た場合もこれに準じ てよいと考える。

抗体亚が初为から高くて不変の場合，または単一血清 しかとれない場合でこれが高い抗体価を示した場合は， 解釈がむつがくなるが，採血病日を考虑し，発病後10 日以上経っていて，CF 価が 32 以上あるものは M.pn.

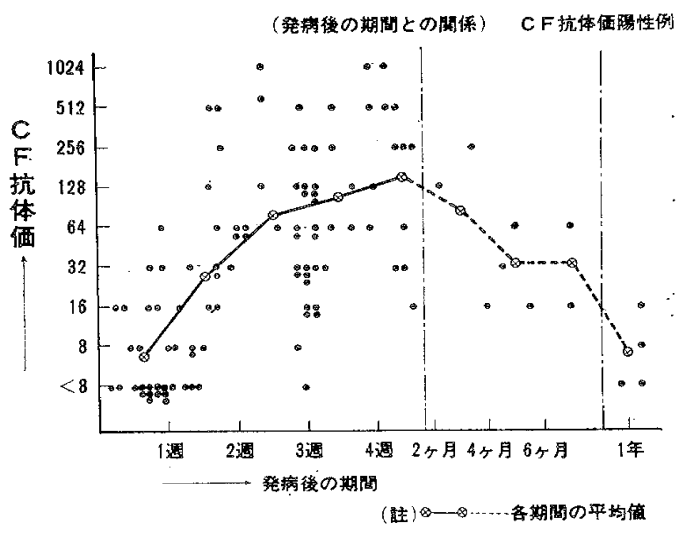

図 3 マイコプラズマ・ニュもニエ $\mathrm{CF}$ 抗体洒の推移
感染症である可能性が強いと考えている。

M. pn. 肺炎と診断された症例につマて, CF 抗体值 が病日とともにどのように動くかをみたのが図 3 であ る. 発病後 2 週加ら 3 週の間に急速に高くなり， 2 力月 頃から次第に低下し始め, 約 1 年後には可のレベルに近 くなる、このことから，ペア血清を採取する場合，第一 血清壮発病後 1 週以内, 第二血清は発病後 2 ないし 3 週 にとるのがよいことがわかる，しかし，第二血清は発病 後 2 力月頃になつても䛦断的価值を失わないと考方られ 吕.

\section{vi. 結 語}

M.pn. 肺炎の実験室内診断法のうち，寒天培地法によ る M. pn. の分離と補体結合反応による血清学的診断に ついて，私達の行なつている方法と成績を述べ若干の考 察を行なつた.

この講演で用いた data は第 64 回日本内科学会総会 で当教室主任北本治教授が宿题報告を担当した際のもの が中心となつている。多くの方な加症例の提供を賜わ。 つたことを記し感謝する。

\section{文 献}

1) 荒井澄夫ほ加(1964)。日本医袤新報, No. 2117, 18. -2) Chanock, R. M., et al. (1962a), Proc. Soc. Exptl. Biol. Med., 110, 543. -3) Chanock, R. M., et al. (1962b) . Proc. Soc. Exptl. Biol. Med. 110, 884. -4) Del Guidice, R. A., et al. (1964). Bact. Proc., p. $71 .-5)$ Someron, N. L., et al. (1963), Amer. J. Hyg., 77, 122.

\section{追加発言}

\section{Mycoplasma pneumoniae による肺炎}

東北大学抗酸菌病研究所小韭科

○新津 泰孝, 長谷川続男, 未武 富子 久保田秀雄, 堀川 雅浩, 小松 茂夫

学童の胸部レントゲン集団検查で発見する晎常院影の 中最も多いのは異型肺炎によるものである。昭和29〜41. 年繁年 $5 ， 6$ 月に行なつた仙台市立全小中高校児童生徒 約 7 万名のレ集団娭査において 異型肺炎は $0.2 \sim 0.3 \%$ に加られ，低学年に多く上学年に少い（図1）

われわれはこの異型䏽炎について疫学的, 躍床的, ウ イルス学的研究莸行なつてきた（新津，1966)。昭和 40 年からは Mycoplasma pneumoniae の病原的役割究 明するとともに関連した実験を行なつてきた。ここに今 迄得た成績の概要を述べてみたい。

方法 間接レ写真撮影の翌日珫影, 肺炎の疑あるもの 老翌日呼出し，大型レ写真，咽頭拭、液，血清採取，白 血球数などの検查を行ない，原則として 3 週後再び呼出: 


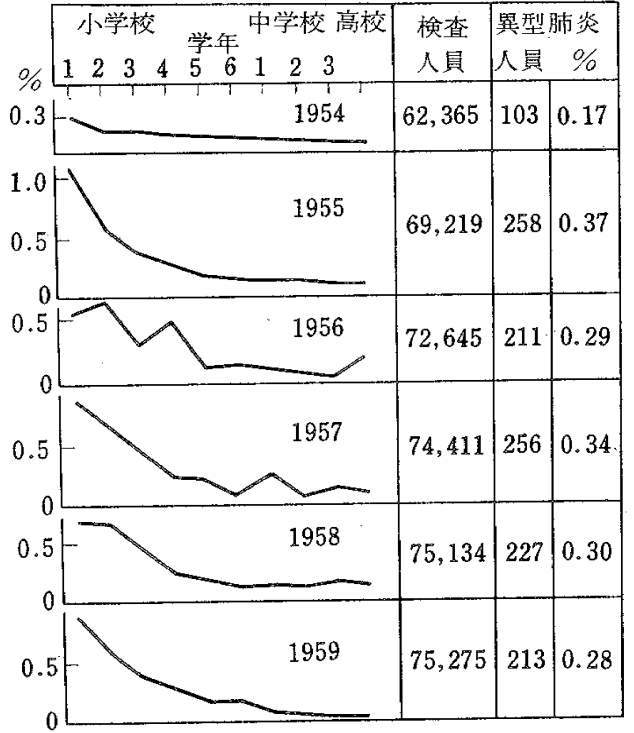

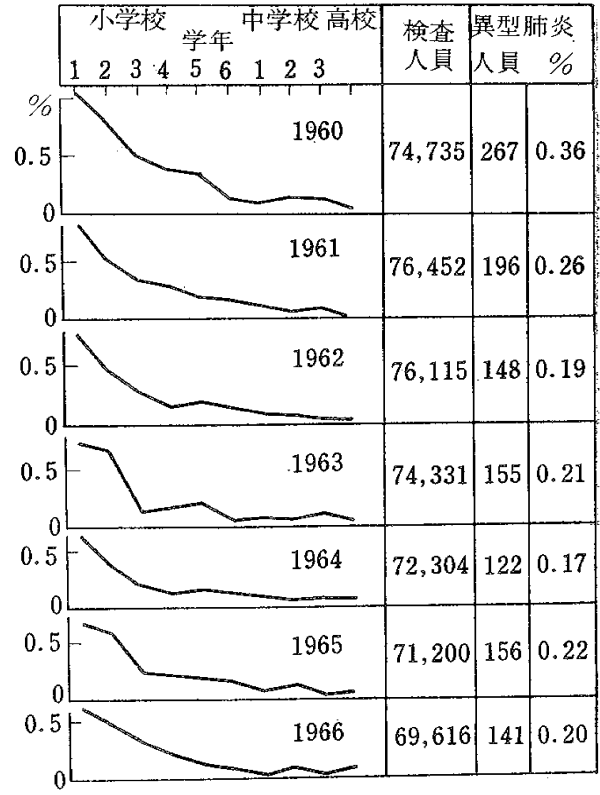

図 1 仙台市学童生徒の胸部レ集団検查による異型肺炎発兌率（每年 5，6月）

してレ写真撮影，血清採取などを行なつた. M. pneum.

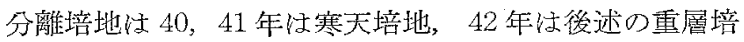
地を用い，咽頭拭い液からの分離を試みた。補結抗原は Kenny の方法に準じ，Mac 株の液体培湌を $1 / 20$ に濃縮 し， $100^{\circ} \mathrm{C} 5$ 分加熱して抗補体作用を除いて使用した。

疫学的観察 昭和 40 年は異型肺炎 131 名中 M. pneum. の分離 8 名, 分離陰性だが補結価上昇 4 名, 分離を試み なかつたがはじめから高い補結価 1 名の計 13 名 $10 \%$ が M. pneum. 肺炎であつた. 41 年は異型肺炎 137 名中 40 年の順序に夫々 2 名, 2 名， 1 名，計 5 名 $3.7 \%$ が M. pneum. 肺炎であつた. 寸なわち年によつて M.pneum. 肺炎の割合は異なる.

40 年の発見状況をみた。型型肺炎は 38 小学校中 36 校 に, 22 中学校 9 校に如ら，その中 M. pneum. 肺炎は 夫及 7 小学校と 1 中学校に多られたにすぎない。某小学 校で注 10 名の異型肺炎発見，7名検查してM.pneum 肺炎は 1 名にすぎなかつたというように同一学校内の肺 炎の一部をしめるにず゙なかつた。

42 年に一家族 4 名全員から M. pneum 分離した. 父己長男は脑炎，次男は気管支炎で肺門リンパ腺腫大の レ像を示し，母澄病せずレ像も正常であつた。もう一 家族娘に肺炎，父に気管支炎があつて 2 人ともM. pneum. を分離した.

以上から M. pneum. 肺炎はこの年龄層では珙型肺炎 の 5 10\%を占め, 学校で一緒になる程度の接触で流そ の発生は一般に流行を来さず散発的であり，より密接に 接触する家族のような環境では流行を来しうることが明
らか上なつた。

ウイルス分離との比較 40 年の成績では集団検査で発 見した筫肺炎からアデノウイルス，パラインフルエン ザウイルス，ヘルペスウイルスを 小学校 $1 \sim 2$ 年で 13 名, 3 年以上 7 名から分離したのに対し, M.pneum. は 小学校 $1 \sim 2$ 年で 2 名, 3 年以上 7 名加ら分離し, ウイ ルスに比べ，上学年からの分離の割合が多いこれ洛上. 学年では M. pneum. による肺炎の割合が低学年より多 いことを示す.

補結抗体亚 図 2 に 40 年の成績安示した。肺炎群で 恢復期血清で M. pneum. に対する補結何をみると, M.pneum. 分離例执よび補結洒上景すなわち M.pneum。 の確実な感染例ではい寸゙れも>64 を示し，>64 を示し た 13 名中 12 名法感染確実例であつた. 残りの 1 名注最 初から補結洒が高く，分離を試みない例であつたが，以 上各らこれも M. pneum. 感染例と侾えてよいと思われ. る. 41 年の成續も同様であつた。すなわち M. pneum。 肺炎の恢復期血清の補結価は高い值を示し，非感染例と はつきり区別され，高い補結抗体価を示するのは $\mathrm{M}$. pneum. 肺炎としてよい成績であつた.

赤血球寒冷凝集反応との関係（図 3 ) 対の血清の高い》 方の寒冷凝集価と M. pneum. 肺炎との関係を办た。肺 炎群と肺炎でない刘照群しを比べると寒冷凝集仾の高い （128倍以上）例は脯炎群に多いから，寒冷凝集佂が高い のは肺炎によつたものであることがわかる。しかし高い 寒冷凝集洒の肺炎の中に注 M. pneum. と無関係の肺炎 があつた。その病因は M. pneum. 以外にも求めるべき 


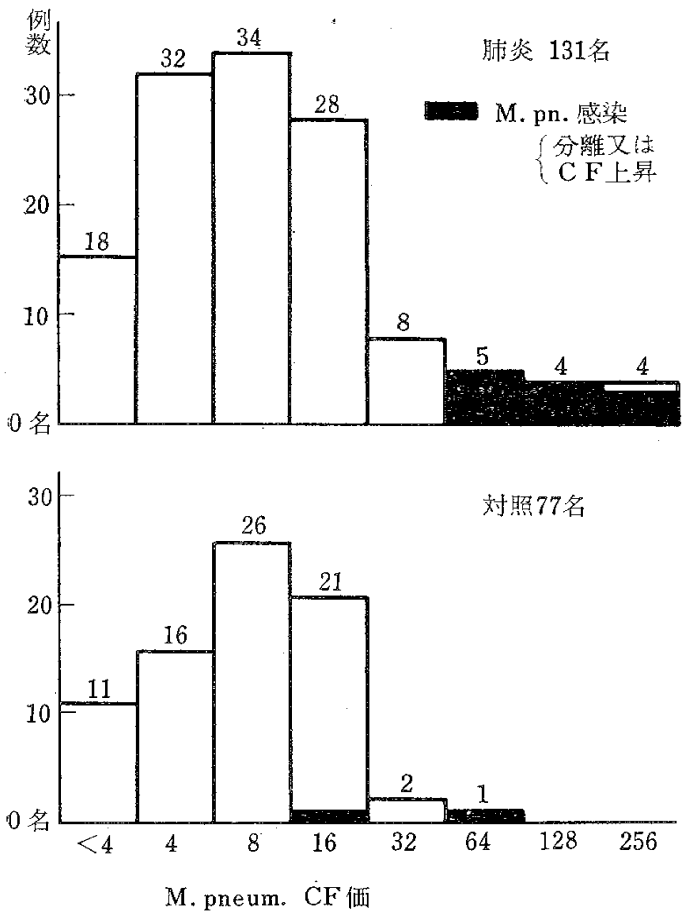

図 2 M. pneum.に対する䋠結伍とその感染 (回復期血清 昭40)

である. したがつて寒冷凝集反応陽性といら点から M. pneum. 肺炎として諭ずることは疑義がある。

分離用重層培地 寒天培地 $1 / \mathrm{ml}$ の上にフェノールレ ッド $0.002 \%$ ，メチレンブラウ $0.002 \%$ ，ブドー 糖 1.0 $\%$ 含有する液体培地 $1 \mathrm{ml}$ 学重層した選択培地で $\mathrm{M}$. pneum. が発育すると青から鮮緑色に変色する。これに $\mathrm{Mac}$ 株階段希釈液学引え寒天培地と比較した。（表 1) 寒天培地で多数のコロニーを示す希釈度で壮変色は 6 日 迄に起つた。 3 コ以下のコロニーを生じた希釈度では 27 日後変色しない培地は 5 本中 1 本だけであつた。

咽頭拭、液を培養して寒天培地と重層培地と罙比較し た. 402 検体中 32 檢体が M. pneum. 陽性であつた. 双方陽性 26, 寒天培地の陽性 2 , 重層培地のみ陽性 4 であつたから，分離率性略同しとい方。

以上微量の M. pneum. 者含有する材料加らの分離に は重層培地は寒天培地に劣ることがあるかもしれないが

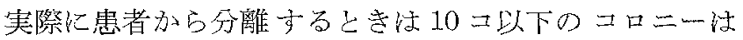
極めて少なかつたこと，重層培地は寒天培地と比べ分離 率が咯↔同でであること，更に沢山の寒天培地について ごく少数のコロニーを影微鏡下に確寒にさがしうるかし いうこととその労力を考えると，この重層境地恃簡単で 優秀な分離用選択培地で岁つて，広く用いることをすす 的压以。

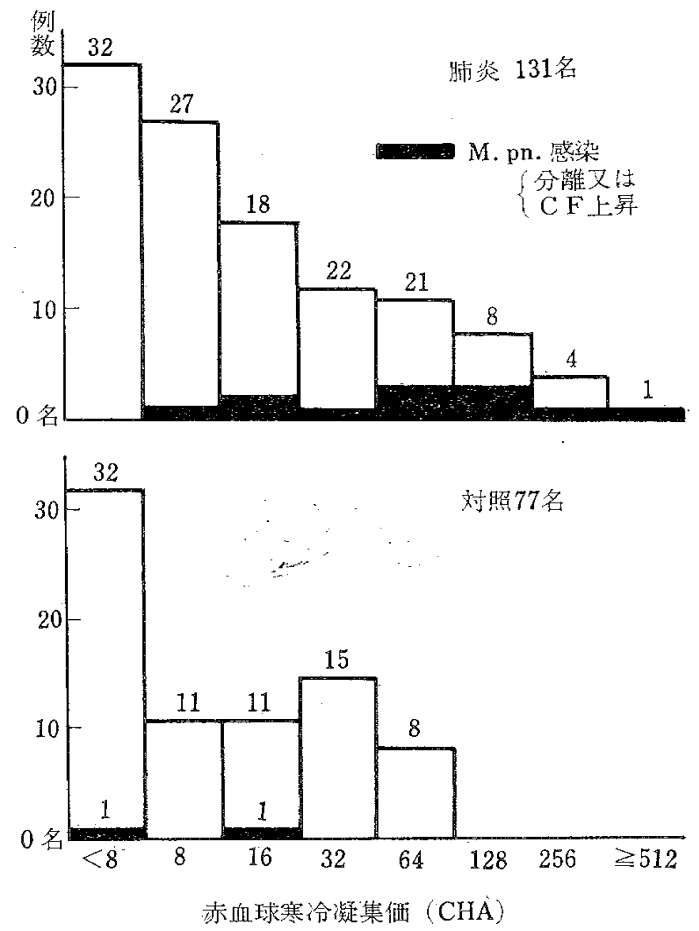

図 3 赤血球寒冷凝集価と M. pneum.の感染 (昭 40)

表 1 重廨培地に叔付変色と篹天培地上のコ ロニー数との比較

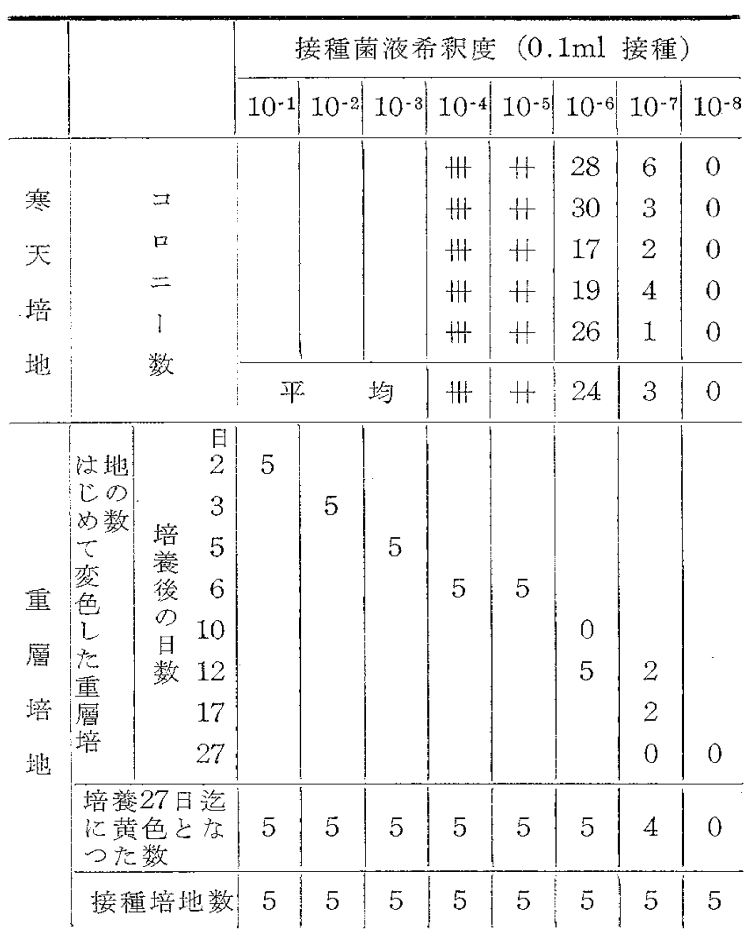


FI (Fermentaition inhibition) test Taylor-Robinson らの血清発育阻止抗体測定法としての FI test について 検討した. microtiter を用い血清階段希橎液 $0.025 \mathrm{ml}$. ブドー 㠊, フェノールレッド含有液体培地 $0.125 \mathrm{ml}$, M. pneum. ( Mac 株) 菌液 $0.050 \mathrm{ml}$ を混し $36^{\circ} \mathrm{C}$ に培 養, 色調 $(\mathrm{pH})$ の変化加占血清の発育阻止莀度を測定し た.

先ず菌液の階段希釈液の夕接種して黄色に変化する 迄の日数をみた. $10^{3} \sim 10^{4} \mathrm{CFU} / 0.1 \mathrm{ml}$ 菌液では $5 \sim 7$ 日で変色することがわかつたので全実験を通じてこの檂 度の菌液を用いた。

M. pneum. に上る免疫前後の家鬼血清, M. pneum. を分離（補結価の上昇した対の人血清について夫々の階 段希橎液をつくり, 菌液の階段希釈液と混じて培養し た. $6 \sim 8$ 日後どちらの血清でも FI 価は上昇していた. すなわち FI test によって M. pneum. に対する抗体測 定が可能であることがわかつた，又との抗体洒效対照が 黄色となつた日の希勫度の菌液の系列で論ずれば，6〜 8 日の培養日数の間では同じ值を示した。血清非働化流 抗体価に有意の差をきたさない。

次に FI 価と補結価との関係をみた。（表2）補結価 $<4$ の 3 名注 FI 価む< 4 であり, 補結価上昇の 3 名で は FI 価も上开し, はじめから高い補結価を示した 5 名 の FI 洒は 4 名注はじめから高く，1名注上昇した。す なわち補結価のうごきと FI 洒のうごきとはよく一致し た。この際 FI洒法補結価より㧍くれて上昇する成績を えた.

53 血清について FI 価と補結価との相関をみた。補結 価の高い血清の FI 価泣をどら上昇した 2 血清をのぞ きいずれも高值を示した。逆に FI 価の高い血清の中に は補結価の低い血清があつた。

どの程度に発育が抑えられたとき抗体㐫りとしている かをみるため，FI 抗体価の高い血清の階段肴鄱液の FI test 老行なつて，各段階の色調の穴から M.pneum. の 定量培養を行ない﨎照と比較した。絬局対照に比心゙て 1/10 1/100 以下に発育が抑えられたとき抗体㐫りとして いることが明らかとなった。

以上 FI test は微量の系で M. pneum. の血清中発䏍 阻止抗体の測定をするのに簡単で確実な方法であり M. pneum. 肺炎の診断に応用できる.

臨床所見 40年のウイルス分離は殆んど全部発症7日 以内の例加で亦った。 これに対して M. pneum. 胡炎 の中に核などの症例が1カ月長いとき恬半年もつづい た後肺炎が発見されて M. pneum。が分離された例が 6 名要る。アクロマイシン又はエリスロシン投与で急速に 症状注軽快しレ所見も改善した。一般にはに゙めから M.

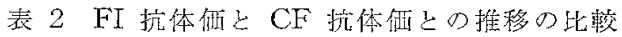

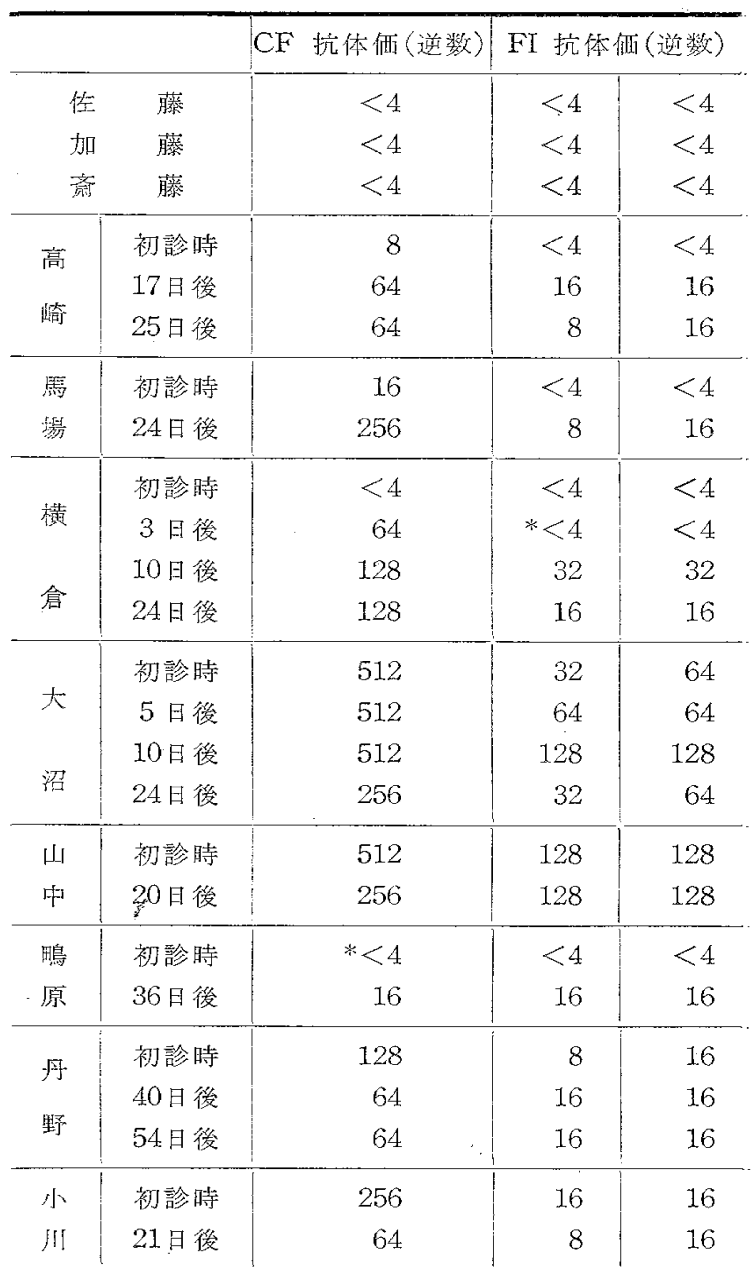

備者 1) 血清は $\mathrm{CF}$ では $60^{\circ} \mathrm{C} 20$ 分 FI test では: $56^{\circ} \mathrm{C} 30$ 分非衝化

2) FI test 2 係列で行つた

3) * FI 価は CF 俰儿就く机て上景

4) 対の血清はす心゙て M. pneum. 肺炎例

pneum. の補結洒恃高く感染が以前から女つたことを示 唆した，又無処置で1カ月の間隔をおいて分離した1例 がある。エリスロシンを投与して症状やレ所見が改善さ れても M. pneum. はな扔検出された 4 例が业る。この 上うに M. pneum. が可成長い間体内に岕ることは一般 のウイル不感染より細菌感染の揚合とよく似ている。

レ写真所見については同時に肺門りンパ腺の腫大を伴: う例がある。（図4）31 名の M.pneum. 肺炎中 8 名約 1/4 飞歹られた. 肺閒リンパ腺腫大は M. pneum. 肺炎 の一つの特徴のように思われる。したがってレ所見のみ、 から站核双極像と誤診する抢先れもある。 


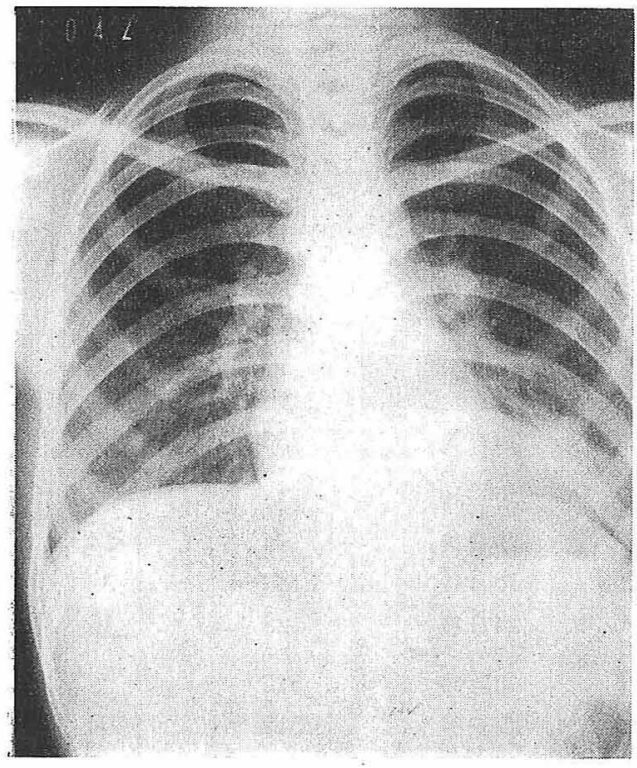

A

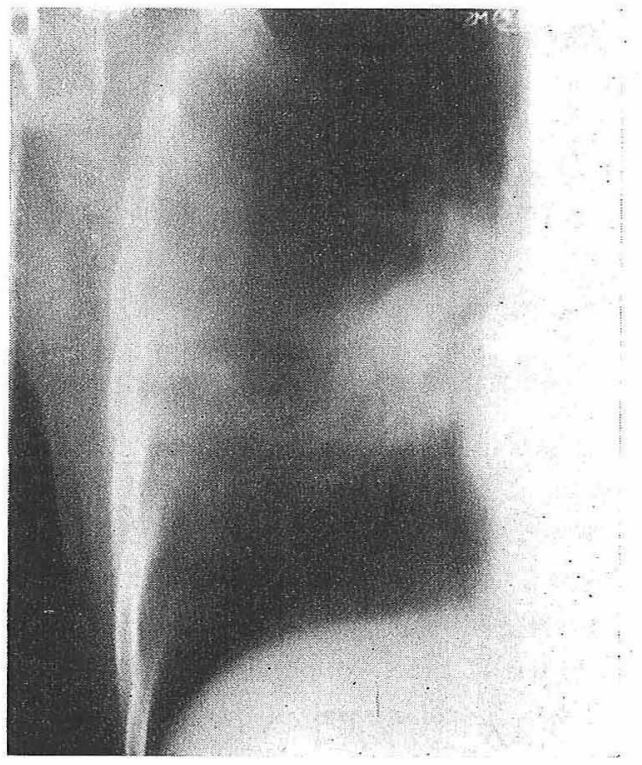

B

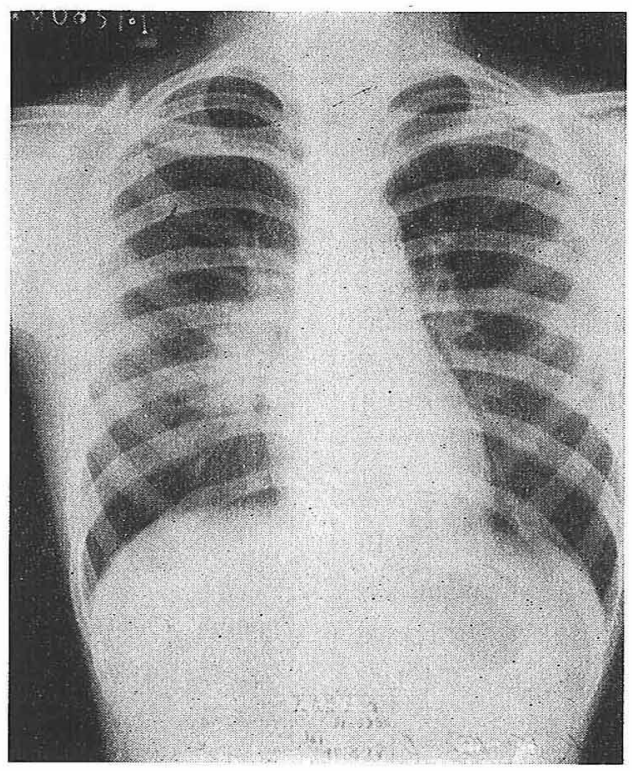

C

泪 4 M. pneumoniae 肺炎にみられた肺門リンパ腺腫大，いずれも M. pneumoniae を分離した. B は A の断層写真で肺門リンパ腺腫大が著明. C 門リンパ腺腫大し双極像様陰影がみえる。 


\section{文 献}

1) Kenny, G. E. and Grayston. J. H. (1965): Eaton Pleuro- Pneumonia-like organism (Mycoplasma pneumoniae) complement-fixing antigen. J. Imm., 95，19. - 2) 新津泰孝（1966）：集団検查て 発見乙た学童生徒の異型肺炎, 日本医事新哌, No。 2177, 31. -3) Taylor-Robinson, D., Purcell, R. H., Wong, D. C. and Chanock, R. M. (1966): A colour test for the measurement of antibody to certain mycoplasma speies based upon the inhibition of acid production. J. Hyg, 64, 91.

\section{PPLO 実験感染の病理像*}

労鮒衛生研究所

河合清 之

本研究は，最近医科学研究所内科臨床研究部で行なわ れた, Mycoplasma pneumoniae の動物への感染実験に 際し，その動物の一部について，肺を中心とする病理組 織学的，電子顕微鏡学的検索の結果を，本シンポジウム にあたつて，取敢えずまとめたものである。

検索材料及方法：医科研内科で行なわれた実験感染 ハムスターの中から選价れ 5 頭が対象で，Mac 標準 秼に上る経鼻感染後 10 日の若いハムスター3 頭, およ び阿部秼(医科研内科分離株)で経鼻感染後 7 日の乳のみ 八ムスター2 頭から成る。動物はエーテル麻酔下に放血 致死せしめ, 直台に肺をとり出して, 右溮は管光抗体法 による検索のため湅結し，左肺は手早く水平断によつて slice とし，カコジル酸で $\mathrm{pH} 6.2$ に緩衝した $5 \%$ グル タールアルデヒド固定液に浸す。更にその組織片を同固 定液に浸しながら双眼䫓微鏡下で切出し部位を確認しつ つ，主気管支，肺門附近気管支，右肺中央部，右肺末梢 部から小組織片を切出し，更に同固定液中で $1 \sim 2 \mathrm{~mm}$ 角に細切した後, 同固定液で $4^{\circ} \mathrm{C} 2$ 時間固定後, 緩衝液 で 1 時閒洗い, s-collidin 緩衙液 $\mathrm{pH} 7.2 \mathrm{O}_{\mathrm{s}} \mathrm{O}_{4}(1 \%)$ で 2 時間再固定，アルコール系で速かに脱水し，Epon 包 埋，薄切後，酶酸りラニル・水酸化鋁重染色を施し， 日立 $11-\mathrm{A}$ 電子顕微鏡により, 加速電圧 $50 \mathrm{KV}, 75 \mathrm{KV}$ によって観察した。

又, PPLO 寒天培地上に発育した Mac 標潐株コロニ 一を，組織䚁察に用いたのと全く同様の経過で処理し， 組織内 mycoplasma の電顥的同定の参考七した.

電影用試料採取後の小組織片および残余の肺組織注，

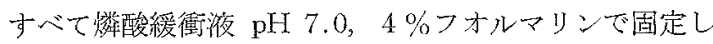
組織学的検索孛行ない，コロニー加らも同様に光顕用パ

* 本報告の一部は，北本治教授によつて，1967年 4 月 第64国日本内科学会宿題報告「ウイルス执よびマイコプ ラスマ性脑炎」中に発表された。
ラフィン切片を作成した.

光学顕微鏡所見 : 剖検に際して, 肺注膨れ, 割面で散 在性の consolidation が認められる。組織学的に梳, 中 等大気管支を中心とす気気管支炎が主像であつて，（写 真 1)，気管支恃全般的に拡張性であるが，場所によつ て治強い収縮に伴う内腔の狭少が認方られ，内腔に恃屡 及好中球が充満して抢りこうした部分から末梢にかけ ての急性気腫が著しい，気管支上皮は時に腫張し，時に

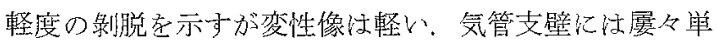
核球执上び好中球の浸潤学伴い，気管支周囲結合組織お よび肺組織に及ぶ場所もある。脑野では末梢気管支炎か

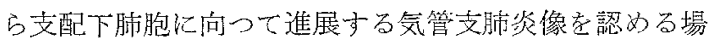
所もあるが，全体としては玟状の急性肺気腫と肺胞壁肥 厚を伴ら所謂胞隔炎が主な変化であつて, 剝離性肺胞等 の像怯しい.

気管・主気管支の病变は軽く，肺門部結合織には中等 度の細胞浸潤を認めるが, 類淋巴組織の過形成はない。 チオニン・ギムザ・Brown and Brenn 変法 (Dogiani, A. S. et al. 1966) 等によつて，少数の菌孛気管支上皮 表面に認めるが，コロニー形成は発見していない。

電子顕微鏡所見 : 寒天培地上のコロニーは培地澡部に 向つて三角堆状に発育している。（写真2）菌は円形。 棈円形ないしは桿状で，多形性がつよく，100mu から $1 \mu$ にわたるが, $400 \sim 700 \mathrm{~m} \mu$ 程度のものが最も多い. 菌体惊則として 3 層加ら成る限界膜学もち，その愿さ 最低值恃約 $70 \mathrm{~A}$ である。 小型の菌体では, ribosome と無構造の基質物質が菌体全般をびまん性に満している が，(写真3)菌体が大きくなるにしたがつてそれ等は贋 々結節状に集合し，その間に低電子密度の間隙が現れ， 菌体が大きく空体状を呈するようになると，ほとんじ菌 体全部艺占めるよりになる、細、組状物質はこうした明 るい部分に認め易く, (写真 4 ) 又菌体六に注 $70 \mathrm{~m} \mu \sim 150$ $\mathrm{m} \mu$ 程度の電子密度の高い基本小体を思わせる構造をも つ円形野が贋々認められ，限界膜と同じ膜構造で囲まれ ている場合と，膜潔造をもたない場合とある。以上の菌の 電子䫓微鏡切片での形熊は Dommeremuth, C. H. et al.,1964 の報告と基本的にはかなりよく一致している. 又菌の限界膜が屚々不明瞭となり，菌体内容の流出を思 わせる所見も多以。

組織内での菌同定は，主として限界膜の存在と内部構 造特に結節状の高電子密度野によつた。気管支上皮で注 菌は線毛および micro villi の間に筑大したような工合

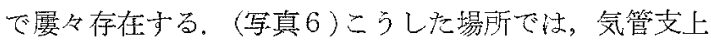
皮細胞の病変法軽い。時に剝離し変性しつつある気管支 上皮学認め，その附近にも菌体学認めるが，菌形態もくず れて拉り，同定に图難を感ずる場合が多い，附近に菌を 
認めない場合でも,気管支上皮には,小胞系の拡張ミトコ ンドリアの空腔化などの変化をみることが多く，又細胞 質の暗化に伴つて micro villi の短少化を少と更に線 毛および micro villi の表面に，電子密度のかなり高い 無構造物質が附着している像，更にそれによって線毛や micro villi が互に接着している像を見ることもある。 気管上皮内および粘膜下組織には菌を確認していない。

気管支壁ないし気管支周囲の浸潤細胞は, 組織球性な いしは淋巴球性の細胞が多いが，時に退行変性像を混 え，その胞体内には変形した菌体を疑わせる小体が愿々 認められるが，明瞭に同定しうる菌体は認められない。

肺胞および肺胞壁については，軽度ながら肺胞内に遊 出した多核球あるいは肺胞喰細胞附近あるいは胞体内 に，明瞭な菌体の少いことは意外である。菌はむしろ肺 胞内では, 多くは破壊細胞（主として肺胞喰細胞）から 遊離した細胞質破片・ミトコンドリアあるい恪子状物 質などと共存しつつ，肺胞内に遊離の状態で見出される (写真 7)。しかしその形態は必ずしも定型的でない場合 が多い。

光学顕微鏡的に胞隔炎と呼ぶ可き部分は，肺璧が正常 の膨張状態を失つて互に接近肺胞の狭少を来している 状況は，電顕的には全く明膫であつて，その意味で無気 肺の状態である。同時に，しかし，肺胞壁自体の変化も
著明で，肺胞壁自体の厚さも増加している．それは主と して, 肺胞壁被覆上皮細胞質の浮腫状の肥厚と毛細血管 内皮細胞質の著しい腫張に由るもので，内皮細胞核の腫 張・白血球血小板等血液成分の停滞もこれに加わつてい る. large alveolar cell も数を増し, lamellar body \& 数多く, 䡌々融合傾向を示寸. 以上の所見は所謂胞隔炎 の実体に就いて示唆的な所見であるが，ここでは樑く立 ち入らない.

討論 : 本検索の範囲は未だ限られたものであるから， 上に述べを所見から引出しうる結論も又限られるが，

1 ) 本検索では Mycoplasma pneumoniae 経鼻感染に よって，八ムスター特に乳のみハムスター肺に感染が成 立していると考光る。气の病変は気管支炎和よび気管支 周囲炎であって，一部は気管支肺炎に進展し，急性肺気 腫㧍よび胞隔炎を合併する，この組織学的所見は，従来 の記載1とも略一致する。

2）電子顕微鏡的による組織内での菌同定は，通常の 電顕標本作成過程によっても可能であり，培地コロニー に於けると全く同様な菌体を主として気管支上皮線毛お よび micro villi 間に認める.組織内でのコロニー形成を 検出できなかつた点，又組織内で基本小体を極めて稀に しか認めなかった点等に関しては更に検索を要しよう。

3 ) 菌は気管支上皮表面・肺胞腔内等細胞外に於て比

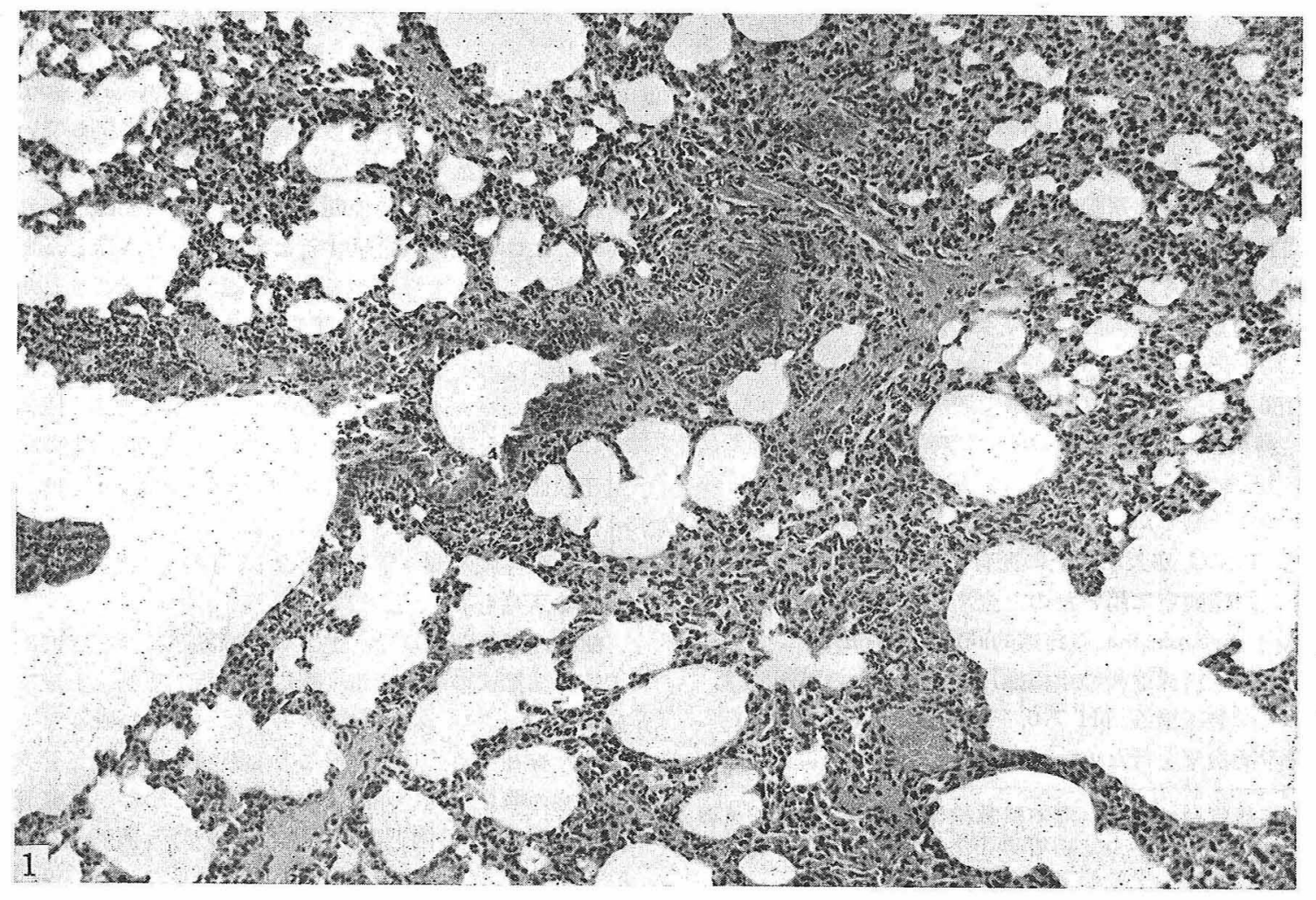




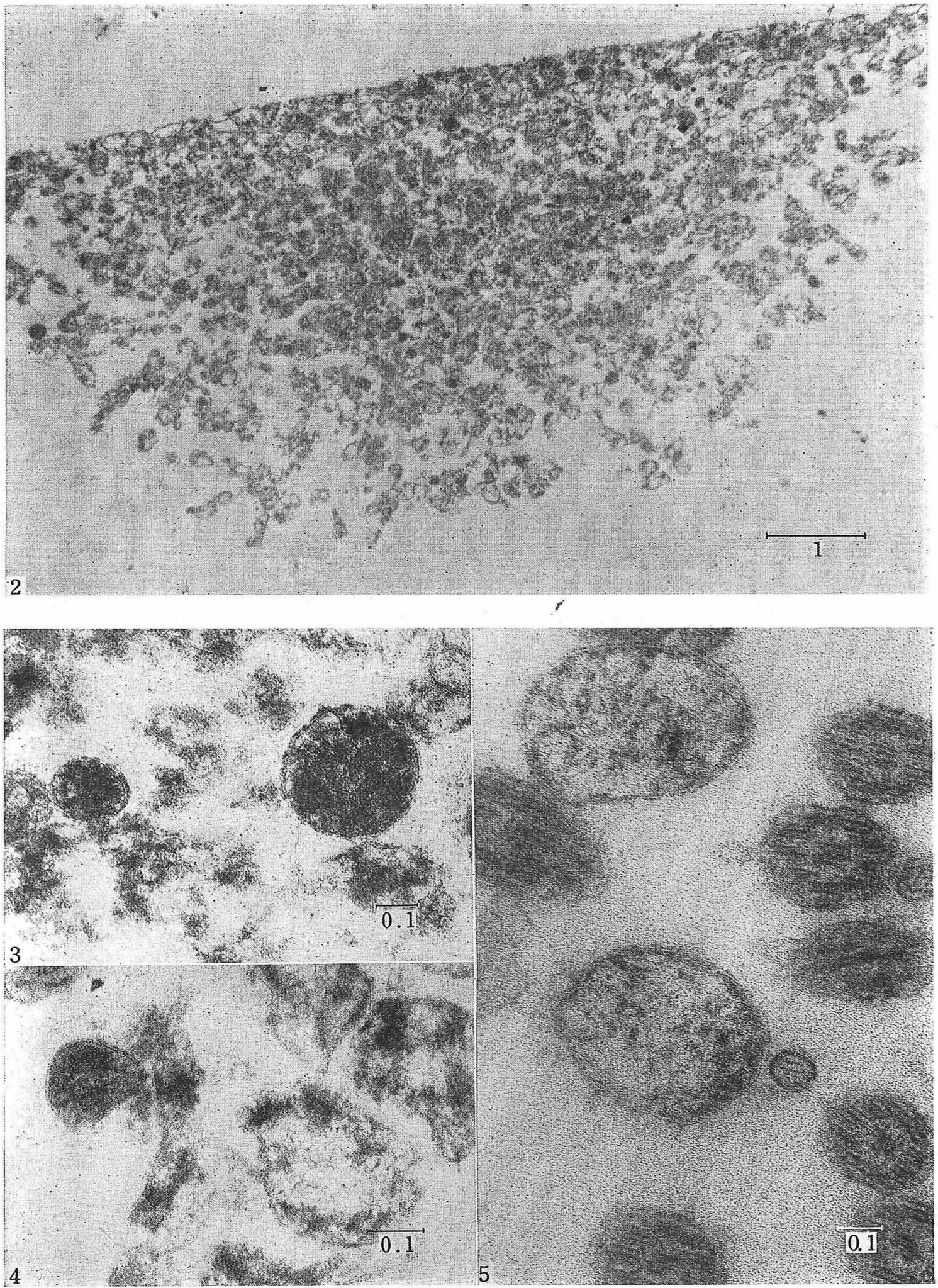



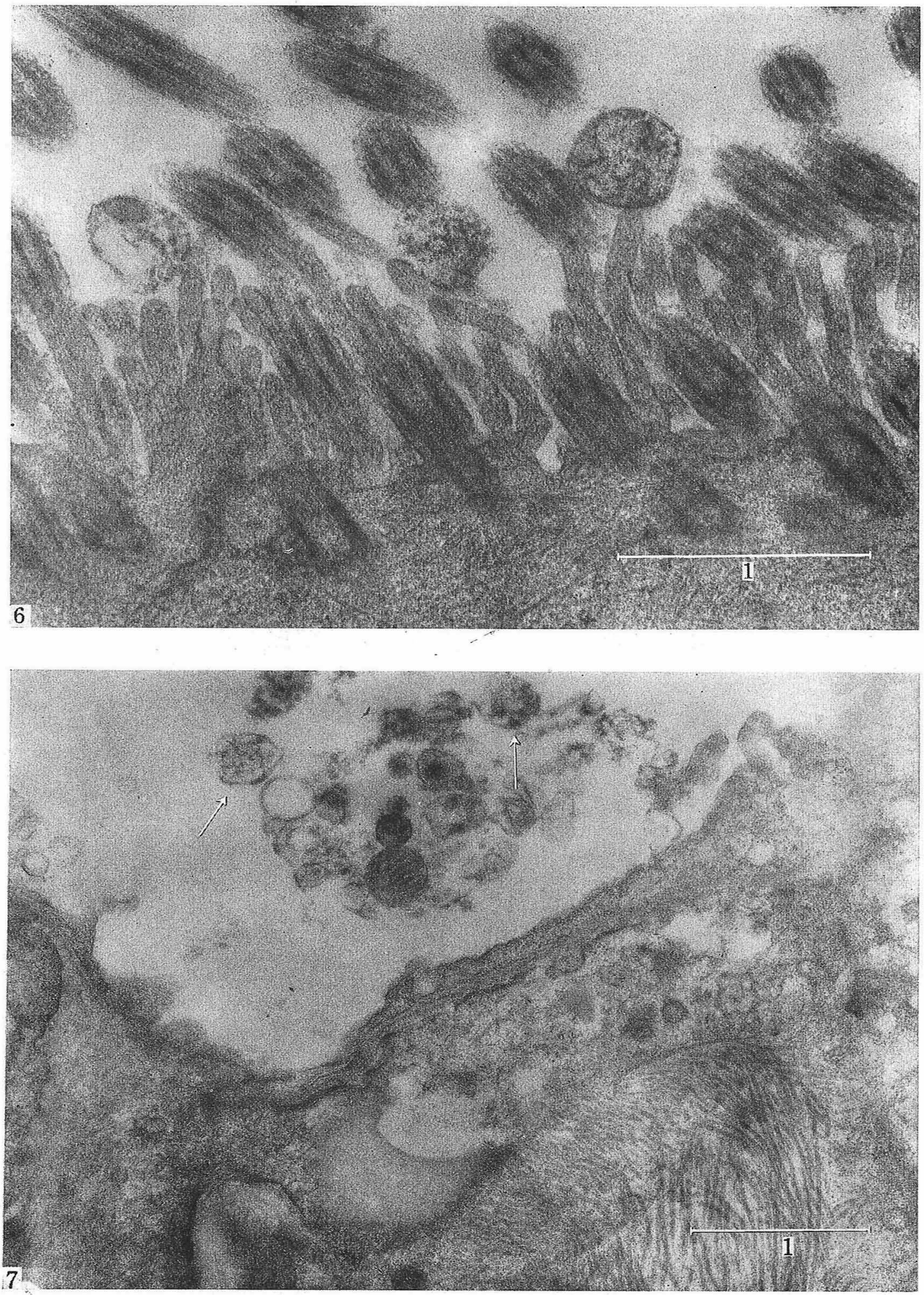
較的容易に同定されるが，一方肺胞喰細胞，肺胞内ない 乙気管支内の好中球，気管支周国浸潤細胞等の胞内体に は極めて稀である、それ等の喰細胞には時に退行変性像 を認め，その胞体内に変形菌体が疑われる小体老霓々検 出するが，定型的菌体注められず，mycoplasma は， 喰細胞中では生存性は弱いと考えられる。

4）胞隔炎の電子影微鏡学的内容に触れたが，その変 化は菌の存在とは必ずしも平行しない。したがつてその
成立機転に関しては，他の要因，例え汸血行障害等も同 時に考慮する必要があるう。

本材料検潆の機会を与えていただいた，北本治教授晾 よで医科研内科の諸先生の御厚意に感謝致します。

\section{文 献}

1) Dajani, A. S. et al. (1966) : J. E. M 121, 1071.

2) Domermuth, C. H. et al. (1964) : J. Bact. 88, 727.

\section{写真 説 明}

写真1。乳のみハムスタ一経鼻感染後 7 日目, 肺, (H.E. 染色)

写真 2 . 寒天培地上のコロニ一の繸断, 大型の空胞状の菌注, 培地深部心るかなり認的られる。

写真 3 . 基本小体 2 個

写真 4 . 空胞傾向老示菌体

写真 5 . 培地標本と全く同条件で作成した組織試料闪の菌体

写真 6 . 気管支上皮線毛間の菌

写真 7 . 肺胞腔内の菌, ( $($ 印), 細胞破片と混在.

\section{3. マイコプラズマと $\mathbb{L}$-form}

一臨床検查の立場から一

東北大学医学部總菌学教室

石田名香雄, 熊谷 勝男

由利 恭子, 菊地 幹雄

\section{1) マイコプラズの栄養要求}

Mycolasma 仕 “もつとも小さい細菌” に分類されて マる，その分類学的位置は Bergeyによれば第 1 図のご とくで，鳥類以下の両棲類なとにも充分その存在が予想 されるに拘らすまだ充分しらべられてない.小さい”と

図 1.マイコプラズマの分類学的位置

Division I. Protophyta Sachs, 1874, emend.

Krassilnikor

Class II. Schizomycetes von Naegeli, 1857

Order X. Mycoplasmatales Freundt, 1955

Family I. Mycoylasmataceae Freundt, 1955

Gen.us I. Mycoplasma, Nowak, 1929

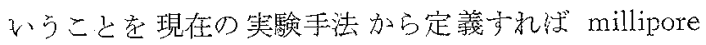
filter の HA $(450 \mathrm{~m} \mu)$ を通過して濾液の方に生物活性 学証明できるということである。電子顕微鏡でみるてれ らしい実体壮 $80 \sim 90 \mathrm{~m} \mu$ の小ささから十数 $\mu$ の大きさま でに拉よで変幻自在である。これを称して当教室では “打化けの Q 太郎”という。いすれにしても最小単位 はインフルエンザウイルスの直径とほぼ等し、球形粒子 である。

“細菌”と何故よぶか子第 1 表に示した培地（実は Hayflik の処方した培地であるが人よんで Chanock の complete medium といら) に接種するとウイルスとち がつて生細胞なしにコロニ一を生じ，増殖するからであ
る、ただしそのコロニー注顕微鏡 40 倍の拉大で寒天の 表面安搜しまわつて始めて認め得るものである。しかし 大量に接種才れば肉眼でも何かが寒天表面に存在寸るこ とを指摘し得る。肉眼で堌殖の有無穵判別するた的各種 の基質と指示葉学寒天培地に加学て招き，色の変化から mycoplasma の生育の有無を判別する（カラースライド 省略)。

表 1 PPLO 寒天培地 (chanock) の組成

\begin{tabular}{lr}
\hline $3.4 \%$ (Difco) PPLO 寒天 & $70 \mathrm{ml}$ \\
$25 \%$ 酵母エキス & $10 \mathrm{ml}$ \\
非加熱ウマ血清 & $20 \mathrm{ml}$ \\
Penicillin GK 塩 & $500 \mathrm{u} / \mathrm{ml}$ \\
酽酸タリウム & $500 \mathrm{mcg} / \mathrm{ml}$ \\
\hline
\end{tabular}

$50^{\circ} \mathrm{C}$ 恒温槽で調整, 蕴径 $4.5 \mathrm{~cm}$ のシャーレに $3 \mathrm{ml}$ づつ分注

1. 糖を分解寸る mycoplama すなわち M. pneumoniae と $M$. fermentans のためには $1 \%$ glucose.

2.この 2 つ以外の classic mycoplasma (比較的大き いコロニーをつくる mycoplasma)のために法 1\% arginine.

3. T-form (tiny の略, 小さいコロニーをつくる) の mycoplasma のために法1\%永素.

各々基質として加え，指示葉以いつれれ phenol red。 glucose の場合のみ黄变が生育を示し, 後二者を基質 とした場合浾変吕生育省示。

第 1 表の培地組織から自明の様にこの培地は血清を多 量に含み $(20 \%)$ ，酵母工キスを多量に含儿だ（10\%） 培地で一般細菌の増殖を抑制するための薬剤は加えてい るが本質的には“御馳走の豊かな”細菌用培地といえる。 粉末 PPLO 寒天 (Difco)の大手が困難であれば第 2 表に 
示した処方の培地(荒井)を用いてもヒト mycoplasmaの classic form に関する限りよく増殖し，したがって従来 考えられていたほど培地に神秘性はない，酵母エキスは 最近 DPN の供給源と定義づけられたとのことである (Hayflick からの私信).

表 2 PPLO 液体培地

その 1 PPLO 液体培地 (Chanock) の組成

\begin{tabular}{|c|c|}
\hline $2.1 \%$ PPLO broth* (Difco) & $70 \%$ \\
\hline $25 \%$ 醭母エキス & $10 \%$ \\
\hline 非加熱ウマ自清 & $20 \%$ \\
\hline Penicillin G K 㻥 & $500 \mathrm{u} / \mathrm{ml}$ \\
\hline 踏酸タリウム & $500 \mathrm{mcg} / \mathrm{ml}$ \\
\hline Glucose & $1 \%$ \\
\hline Phenol red & $0.002 \%$ \\
\hline \multirow{2}{*}{\multicolumn{2}{|c|}{ 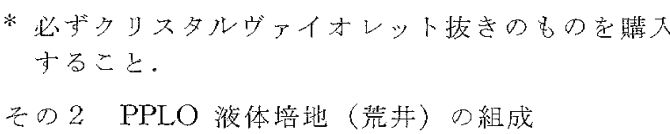 }} \\
\hline & \\
\hline $1.7 \%$ heart infusion broth (Difco) & $70 \%$ \\
\hline Peptone（極東） & $0.3 \%$ \\
\hline $\mathrm{NaCl}$ & $0.2 \%$ \\
\hline $25 \%$ 酤罗エキス & $10 \%$ \\
\hline 非加熱ウマ血清 & $20 \%$ \\
\hline 醋酸タリウム & $500 \mathrm{mcg} / \mathrm{ml}$ \\
\hline Glucose & $1 \%$ \\
\hline Phenol red & $0.002 \%$ \\
\hline
\end{tabular}

pH 7.8 亿調整

加えた一般細菌の増殖阻止薬剂の内 penicillin は周知 の抗菌スペクトルをもち、これで阻此されないところに mycoplasma が “細肘壁の称い細菌”と定義される所 以のむのがある。醋酸タリウム（thallium acetate）の 抗菌スペクトルは第 3 表に示した. のちほぞ mycoplasma と細菌の L-form との関倸にふれたいと思うが Streptococcus とか Proteus とか L-form が誘導され易 いといわ礼る細菌が一般に醋酸タリウムの $500 \mathrm{mcg} / \mathrm{ml}$ で阻正され難、攧间のあることを最近われるれ知つ た.この物質の作用機作について既に研究があるのか否 か寡聞にして知らない。

いられにしても mycoplasma の栄養要求をさぐり岕 てようとすると“血清を $20 \%$ という大量に加えた”細菌 培地が必要というところに落ち着く，血清は(1) cholesterol を多量に含みこの cholesterol 分子がそのまま mycoplasma 表面の細胞膜にとりこまれ unit membrane が伸長するといわれて括り，(Klieneberger-Nobel，E。 et al.1962) (2) また血清法ある種のリポ蛋白の供給源 でこの蛋白と各種のメタボライトが結合し active trans-
シンポジウム

port されるために essential ということになつている (Hayflick, L. \& Chanock, R.M., 1965).われわれのし らべた範国内で cholesterol の合成阻害剂である Triparanol MER-29) は原虫である Tetrahymena の増殖を 阻止するが mycoplasma の増殖恃阻止しない。 また

表 3 各種細菌の酽酸夕リウムに対する感受性

\begin{tabular}{ll}
\hline Microorganism & Sensitivity \\
\hline Staphylococcus aureus & $\mathrm{S} \mathrm{R}$ \\
Staphylococcus epidermidis & $\mathrm{S}$ \\
Streptococcus hemolyticus & $\mathrm{R}$ \\
Streptococcus viridans & $\mathrm{R}$ \\
Streptococcus faecalis & $\mathrm{R}$ \\
Diplococcus pretumoniae & $\mathrm{S}$ \\
Neisseria gonorrhoeae & $\mathrm{S}$ \\
Bacillus anthracis & $\mathrm{S}$ \\
Bacillus cereus & $\mathrm{S}$ \\
Candida albicans & $\mathrm{S}$ \\
Proteus mirabilis & $\mathrm{S}$ \\
Proteus vulgaris & $\mathrm{S} \mathrm{R}$ \\
Proteus rettgeri & $\mathrm{S} \mathrm{R}$ \\
Proteus morganii & $\mathrm{S} \mathrm{R}$ \\
Pseudomonas aeruginosa & $\mathrm{S}$ \\
Escherichia coli & $\mathrm{S}$ \\
Shigella flexneri & $\mathrm{S}$ \\
Shigella sonnei & $\mathrm{S}$ \\
Salmonella typhi & $\mathrm{S}$ \\
Salmonella paratyphi B & $\mathrm{S}$ \\
Citrobacters & $\mathrm{S} \mathrm{R}$ \\
Aerobacters & $\mathrm{S}$ \\
Hafnia & $\mathrm{S}$ \\
Serratias & $\mathrm{S}$ \\
Klebsiella pneumoniae & $\mathrm{S}$ \\
\hline &
\end{tabular}

$\mathrm{S}$ : Sensitive at $500 \mathrm{mcg} / \mathrm{ml}$ of $\mathrm{TA}$

S R : Sensitive at $1000 \mathrm{mcg} / \mathrm{ml}$, but resistant at $500 \mathrm{mcg} / \mathrm{ml}$

$\mathrm{R}$ : Resistant at $1000 \mathrm{mcg} / \mathrm{ml}$

Quilligan (Eaernstein, H.D. \& Quilligan. J. J., 1963) が示唆した線に沿つて家鬼に cholesterol を多量に経口 投与し，コレステロール血漿になつたことを定量的に確 か姉た上で培地に加えてみたが，それより cholesterol 濃度の低い馬血清で $M$. pneumoniae は山るかによく 堌殖し, cholesterol のみが determinant という印象を 与えない，ところがひとたび家鬼血清の培地に馴化され たコロニーはたとえ cholesterol が少なくともこれまた 実によく堌殖し，われわれ㤝これで増殖させた myco。 plasma を家鬼に免疫原として用いている，と名角現実 の問題にたち返れば一般の mycoplasma の増殖には馬 
血清が何といつてもベストで，この大手が容易か否かで マイコプラズマ研究の進涉度が左右される、いづれの培 地を用いても最高増殖を得るため馴化の必要がある事は この微生物にとつてまさに特徴的な事である.

以上マイコプラズマという微生物—Catabolism \& anabolism も兼衫備えた世界最小の微生物——定義 し, 特徵つけるために最小要求培地 (minimum essential. medium)方何であるか子生化学的に明らかにすれ汪，も つとはつきりした形になる筈であるが，ての辺な研究 は行きとどいていない. しかし将来の方向として「cholesterol ないしその誘尊体を生育のため絶対必要とす る」微生物群で「細胞壁を欠く」といつた定義が可能の 様に思われる。ムラミン酸，デイアミノピメリン酸の様 に細胞壁のムレイン（ムコペプチド）の構成成分が一部 証明されたものもあるが一般的に“存在せず”といつて よろしい (Hayflick, L. \& Chanock, R. M., 1965, Smith, P. F. 1964)

Mycoplasma の堌殖に必要な，苏るい瑐殖を促進す る cholesterol 類似構造は

(1) ステロイド骨格 (cyclopentanophenanthrene ring) とコレステロールの side chain (図示) が完全に必要で 市り

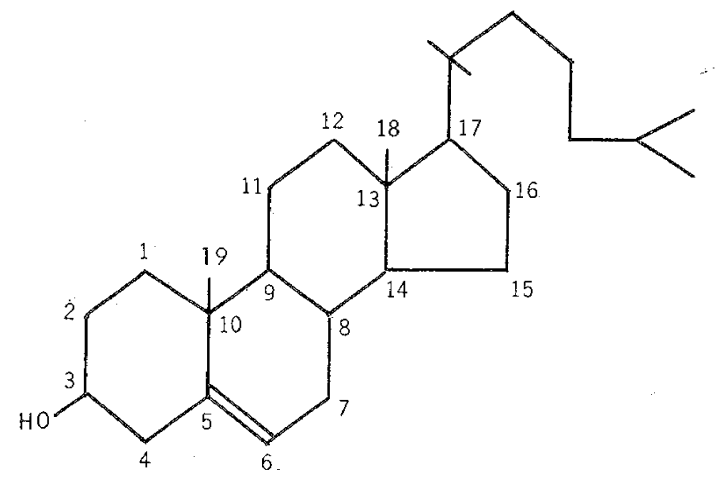

(2) 3 位に水酸基の存在はその配位に関係なく必要で ある。

細胞膜が動物細胞のそれに類似し, 細菌とちがつて細 胞壁をもたないところから，“mycoplasma は原虫”とい う考方方 (Hayflick, L \& Chanock, R. M. 1965) が部々持たれている.しかし動物細胞から得られたリボゾ 一ムが一般にシクロヘキシミドに感受性が高いのに比 ベ,この細胞のリボゾームに於叮る蛋白合成はシクロヘ キシミドに耐性である。亦すす“抆化讨のQ太郎”の 感省深くする。

\section{2) ヒトに寄生するマイコプラズマ}

表 4 kマイコプラズマの定義, 表5にひとから分離さ
れるマイコプラズマの一覧表を揭げた，今回の臨休りイ ルス談話会を目標にわれわれが焦点をしぼつた研究目的 のいとつである“ヒトの鼻咽腔一あるい性吸道加ら分 離されるマイコプラズマの病原的意義”についての考察 を次章によとめるが前にここでその研究背景に子れ て就きた。

\section{表 4 マイコプラスマとは？}
1) 無細胞培地で增殖可能
2) 最小 $(125 \sim 150 \mathrm{~m} \mu)$ の增殖単位
3) 多形性
4) 増殖のためステロールと蛋白を要求
5) ペニシリン耐性，テトラサイクリン感性
6) 抗体で增殖阻圵
7) 細菌人復帰む寸

実は教室の”mycoplasma 研究には二つの流れがあつて ひとつは mycoplasma による細胞の transformation の 研究である(本間, 本田)。これは如何にしたら (1)mycoplasma がそれのみで増殖できない液体培地中でも細 胞を加えることによつて増殖できる様になるか（表 6)

(2) 組織培養の液中にどんな抗生物質を加六たら mycoplasma 社その増殖惊此し，交わよくば液上り細胞を 好んで細胞内へもぐりこめるか，といつた 2 つの研究目” 標に分割することができる. Mcpherson をはじめ plasma による transformation の研究 (Macpherson, I. \& Russell, W., 1966 : 本間, 石田, 1968) 壮多くの示 唆に富さ拘らず, 内容は速報的で, 説得力に欠ける. いずれにしても教室の主研究である「微生物一殊にウイ ルス一によるヒト細胞ゲノムの転換」という道すじに沿 つた研究の流れである，他のひとつの流れがここで述べ る内容で一般に「ひとにつくマイコプラズマのうち $M$. pneumoniae の多が病原菌で他の mycoplasma は病原性 でない」といつた定説は信じてよいのか否かという疑問 から出発した仕衰である。

表 5 の mycoplasma の中でヒトの下の出口すなおち泌 尿器加らのみ分離される $M$. fermentans をのぞいて $M$. hominis, $M$. salivarium, $M$. orale type $1,2,3$ (orale type 1 は一時（1966年）M.pharyngis とよばれ たが再び orale type 1 という呼称比もどっている), 及び M. preumoniae の 6 つの species が上の出口士 なわち鼻㸶腔より分離される mycoplasma である。表 5 でも明ら加な様に M. pneumoniae 江異型肺炎 (PAP) といら病気の時にの分離され，M. hominis が上の出 口すなわち oropharynx より分離されることは稀であり また $M$. orale の type 2 と 3 㹥最近その存在が知られ たばかりで分離頻度は低いことになつてる。したがって 
表 5 とトから分離されるマイコプラズマ (Purcell, R. H. \& Chanock, R. M, 1967)

\begin{tabular}{|c|c|c|c|}
\hline Mycoplasma & No. of Serotypes & Site of Recovery & Assoctation with illness \\
\hline $\begin{array}{l}\text { M. hominis } \\
\text { type } 1\end{array}$ & $\begin{array}{l}\text { Multiple : related but } \\
\text { distinguishable }\end{array}$ & $\begin{array}{l}\text { Genitourinary tract (common) } \\
\text { Oropharynx (uncommon) } \\
\text { Pleural fluid, blood (rare) } \\
\text { Products of abortion (rare) }\end{array}$ & $\begin{array}{l}\text { Pelvic inflammatory disease (not definite) } \\
\text { Pharyngitis, pneumonia (not definite) } \\
\text { Septicemia (not definite) }\end{array}$ \\
\hline M.salivarium & 1 & Oropharynx (common) & None \\
\hline $\begin{array}{l}\text { M. orale type } 1 \\
\text { (M. pharyngis) }\end{array}$ & 1 & $\begin{array}{l}\text { Oropharynx (common) } \\
\text { Bone marrow (rare) }\end{array}$ & $\begin{array}{l}\text { Isolated from bone marrows of leukemic } \\
\text { children (rare) }\end{array}$ \\
\hline M.orale type 2 & 1 & Oropharynx (rare) & None \\
\hline M.orale type 3 & 1 & Oropharynx (rare) & None \\
\hline M. fermentans & 1 & $\begin{array}{l}\text { Genitourinary tract } \\
\text { (uncommon) }\end{array}$ & $\begin{array}{l}\text { Inflammatory diseas of the genitourinary } \\
\text { tract (not definite) }\end{array}$ \\
\hline $\begin{array}{l}\text { M. pneu- } \\
\text { moniae }\end{array}$ & 1 & $\begin{array}{l}\text { Oropharynx (uncommon except } \\
\text { when associated with illness) } \\
\text { Middle ear (rare) }\end{array}$ & $\begin{array}{l}\text { Upper and lower respiratory tract disease } \\
\text { (common) } \\
\text { Myringitis (rare) } \\
\text { Various cutaneous, ceurologic conditions } \\
\quad \text { (ont definite) }\end{array}$ \\
\hline "T-strains" & Multiple : unrelated & $\begin{array}{l}\text { Genitourinary tract (common) } \\
\text { Oropharynx (uncommon) }\end{array}$ & Urethritis (ont definite) \\
\hline
\end{tabular}

表 6 Growth of $M$. pneumoniae in Tissue Culture and Cell-free Menium

\begin{tabular}{c|l|c|c}
\hline Cell & $\begin{array}{c}\text { Basal } \\
\text { Medium }\end{array}$ & Serum & $\begin{array}{c}\text { Max. Titer } \\
\text { (CFU/ml) } \\
\text { Obtained }\end{array}$ \\
\hline- & PPLO Broth & $10 \%$ Horse & $10^{8}$ \\
- & Y L E & $10 \%$ Bovine & $10^{2}$ \\
- & Y L E & $10 \%$ Horse & $10^{4}$ \\
HeLa & Y L E & $10 \%$ Horse & $10^{8}$ \\
L & Y L E & $10 \%$ Horse & $10^{8}$ \\
Calf Kidney & Y L E & $10 \%$ Bovine & $10^{6}$
\end{tabular}

M. salivarium と $M$. orale type 1 がもつとも頻度高 く分離されることが予想され，また研究結果もこの予想 と一致した.

またこらいつた研究を企図することが可能になつた背 景将次のごとくである。(1)すでに我国でも mycoplasma の研究方法が地について（佐々木正五を班長とする“癌 とPPLO”なる研究班の成果（本閒，石田，1968）索 照されたし)，T-strains 除いた classic mycoplasma は正しく分離し得るという自信がついた。(2)そこで健康 人についてマイコプラボマ一般の存在索 throat swab t 用いてしらべてみたところ，分離できる人とできぬ人と がいた。(3)るとこの微生物はどんなヒ下にも resident になり得る訳ではなくこの微生物が“存在する条件”之 いつた樣なるのがあり，そらいつた条件を与えられた人 で最高度に增殖が起ると Candida と同稼に“病原性を 発揮する”可能性があると考えた。 (4)として現に M. hominis 1 病原性がないことになつているがこれを大量 に春験感染させるとつよい pharyngitis 学起すことが知 られている. (Mufson. M. A. et al., 1956) (5) したが つて M. preumoniae の病原性についての検索蝮床家 に任せて掠ても他の mycoplasma の存在についての研 究怯われわれ基礎の微生物学者が明らかにする必要があ ると考えた。以上が実験背景である。

\section{3）慢性呼吸器疾患（ヒトの CRD）からのマイコ プラズマの分離}

患者はす心て東北大学中村内科および放射線科大院の 患者で患者の選択注中村内科松本慶蔵講師による。分離 材料注 sputa 又仗 throat swab washing. 培地仕 Chanock の寒天培地を径 $6 \mathrm{~cm}$ のシヤーレに $4 \mathrm{ml}$ 分注し, sputa はその homogenate の $0.1 \mathrm{ml}$ を, throat swab washing 恃その $0.1 \mathrm{ml}$ を中央に滴下し塗抹した. フラ ン器の温度は $36^{\circ} \mathrm{C} ， 4$ 日をすぎると大体コロニー学認 为得る様になる。そして1週間寸ると注注るものは出 つくすが，観察期間は 10 日とする。コロニーと認めた ら push block technique で継代し，すくなくとも3 回 は継代する。約 3 力月の寒鈳のち大体コ口ニーの性状で mycoplasma の種類住判別できる様になつたが，このた わにはコロニーを必ず継代する必要が市り初代のコロニ 一では判別できない，ただし最終的な同定はすべて特異 血清を用い中和反応によった（Stanbridge，E＆Ｈayflick, L., 1967).

M. preumoniae 壮モルモットでもニワトリでも赤血 
表 7 人由来のマイコプラスマの性状

\begin{tabular}{|c|c|c|c|c|c|}
\hline & M. pneumoniae & M. hominis & M. orale & M. salivarium & M. fermentans \\
\hline 健康人のどからの分離 & - & - & + & + & - \\
\hline 嫌気性の壃殖 & + & $H$ & tt & H & + \\
\hline 好気性の增殖 & H & + & + & + & + \\
\hline コロニーの大きさ & 中 & 大 & 小 & 大 & 中 \\
\hline$\beta$ 溶血の有無 & + & - & - & - & - \\
\hline へモアドソープション & + & - & - & - & - \\
\hline 寒天からの㔀離 & - & 周辺 $(+)$ & - & 周辺 $(+)$ & - \\
\hline Glucose 分解 & + & 一 & - & - & + \\
\hline Arginine 分解 & - & + & + & + & - \\
\hline
\end{tabular}

表 8 CRD からマイコプラズマの分離成緬

\begin{tabular}{|c|c|c|c|c|c|c|}
\hline Patient & Sex & Disease & Species of PPLO & $\underset{1}{\text { Time of }}$ & $\begin{array}{c}\text { isolation } \\
34\end{array}$ & $\begin{array}{c}\text { Duration } \\
\text { Period } \\
\text { (Days) }\end{array}$ \\
\hline Yasuda & 令 & $\mathrm{CPE}^{*}$ & M. salivarium & $+\quad+$ & + & (15) \\
\hline Hozawa & 今 & $\mathrm{CPE}+$ Asthma bronchiale & M. orale 1 & + leave & hospital & \\
\hline Watanabe. S & 우 & Asthma bronchiale & M. orale 1 & $+\quad+$ & + & (15) \\
\hline Aizawa & 今 & $\mathrm{CPE}$ & M. salivarium & $+\quad+$ & & (4) \\
\hline Sayama & 우 & $\mathrm{CPE}$ & M. salivarium & $+\quad+$ & + & (22) \\
\hline Shoji & $\widehat{\delta}$ & Pulmonary tuberculosis & M. salivarium & $+\quad+$ & & (29) \\
\hline Watanabe. M & $\S$ & Pulmonary tuberculosis & M. orale 1 & + & & (39) \\
\hline Naknishi & $\widehat{\delta}$ & Pulmonary tuberculosis & M. orale 1 & + & & \\
\hline Tozawa & $\lesssim$ & Healthy & M. orale 1 & - & & (46) \\
\hline
\end{tabular}

* Chronic pulmonary emphysema

球をコロニーの上に滴下するとコロニー周辺にへモアド ソープションを起し容易に鑑別される，之等の性状をま とめたのが表 7 である。申しおくれたがいずれの mycoplasma d媏気性で培養した方方コロニーの出現も1〜 2 日早く, コロニーの成長も早いので（コロニー数注好 気性の条件と較べ大して変らぬ）水老充分含本せたデシ ケーターにシヤーレを执さ $N_{2}$ gas をボンベから 2 回 flash して培飺している.

患者からの分離結果㳖表 8 に示した通りでいずれ原著 として発表の予定で岁る、いずれにしても mycoplasma が分離される患者からは毎週つつけて分離される。し たがつて sputa 学沢山排出している CRD 患者の中で mycoplasma 分離陽性の CRD と陰性の CRD とに二.

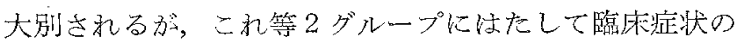

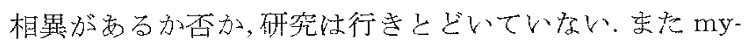
coplasma を排出している患者のあるもの壮4倍ないし 8 倍の中和抗体を証明するが，ある患者は中和抗体学証 明できない.

前述した様にこの研究の初期に健康人からの分離頻度 が低く，CRD患者からの分離頻度が高かつたため mycopasma のCRD への etiological significançe を考えた
訳であるが次の表 9 でも明らかな様に健康人（結核患者 を含む) でも throat swab を用いると分離率泜く, sputa を用いると分離率が高いことが後に判明した。 こ のことはわれわれのマウスからの M. pulmonis の分離 経験，才なわら気管支からの分離率が呼吸道のらちでも つとも高い事実（二階堂他，1966）とも一致し，mycoplasma の呼吸道に於汀る存在箇所の特異性を示してい るものと思う。この意味でわれわれは問題点の鉾先を修 正する必要があり CRD 患者の呼吸道のどの部分に mycoplasma は存在し, 中和抗体を産生するほどに増殖し た場合 mycoplasma 特有の病樂をつくるまでにいたろか

表 9 健虔人と CRD 患者加らの分離率の比較

\begin{tabular}{c|c|c}
\hline Disease & $\begin{array}{c}\text { Healthy } \\
\text { Adults } \\
\text { Specimens }\end{array}$ & $\begin{array}{c}\text { Chronic } \\
\text { Respiratory } \\
\text { Disease }\end{array}$ \\
\hline Swab & $1 / 10$ & $0 / 11$ \\
Sputa & $3 / 23$ & $5 / 15$
\end{tabular}

いたらぬのかを明らか沈する必要がある。

4) Mycoplasma と I-form とのちがい

われわれはごく最近をで L-form をわれわれの手で研 
究した経験がなかつた，ところが mycoplasmaの綜説を まとめる際必ずL-formとの相異に言及する必要があり， そで他人の綜説を注意深くよむが，何処に果して mycoplasma と L-form との相異があるのがつきりしない のである. ところが臨床微生物学の領域でこの辺の問題 を提起する報告が最近2つあらわれた。 ひとつはイギリ スの Gutman(1967) らの報告で尿路感染のProteus 菌吕 尿から消えている閒 Proteus は L-form の形で尿に証 明され（これは普通の細菌用培地では増殖しないがマイ コラズマ用培地では堌殖する)，しかしその内にまた親の Proteus 菌が証明される stage 堂迎えるというサイクル の証明である。もうひとつはやや古いが 1962 年の Godzeski (1962) らの報告で従来の概念と異なり「L-form の 誘導にはペニシリンの様な細胞壁の合成阻害剤を必ずし も必要とせず，テトラサイクリンでもエリスロマイシン でも不完全阻止濃度孝用いれば L-form が誘導できる」 し，しかも「でき上つた L-form 注誘導の歴史を反映し 例えばエリスロマイシンで誘尊した L-form はエリスロ マイシンに渜性である」という記載でことに第 2 の結諭 はわれわれが長い間いだいていた教義すなわち「mycoplasma も L-form も一般に蛋白合成阻害を作用機作々 するマクロライド群に感受性が高い」と相反するもので
ある、、づれにしてもこの事を確める事を念願に菊地は Proteus 菌を用い L-form の誘尊について次の実験を行 なつた。

5) Proteus mirabilis の L-form 変換 (transformation) と先祖返り (reversion)

先ず， stable L-form の誘尊条件をしらべた。TSBで 3 時間培養した P. mirabilis を，馬血清学 $20 \%$ そ゚ニシ リンを $100 \mathrm{mcg} / \mathrm{ml}$ 加えた heart infusion agar(L-HIAで 48 時閒培養すると, 所謂 fried egg shape のコロニ ーができる(表10)。このコロニーが L-form のコロニ ーで女つて L-colony とよ代れているが，マイコプラズ マのコロニーよりやや大きい. このコロニーを上述の L-HIA で5〜6代継代した後, 更に, L-HIAより寒天 を除いた液体培地 (L-HIB) に接種し, 約 24 時間培養す ると，図 2 の下段の様な ( 1 day)，直径約 $2 \sim 5 \%$ の円 形の large body に成長する。更に5日後には, この large body が小さな顆粒の団であることがはつきりし てくる (以上染色注メチレン青アルコールル 飽和溶液)。 この状態の L-form はペニシリンおよび血清を含まない 培地で培養しても，もはや bacterial form にもどるこ となく、 L-form として増殖する(表10), すなわち stable L-form でせる。この5日目の large body 省乳錸

表 10 Proteus 菌加らの Stable L-form の誘導

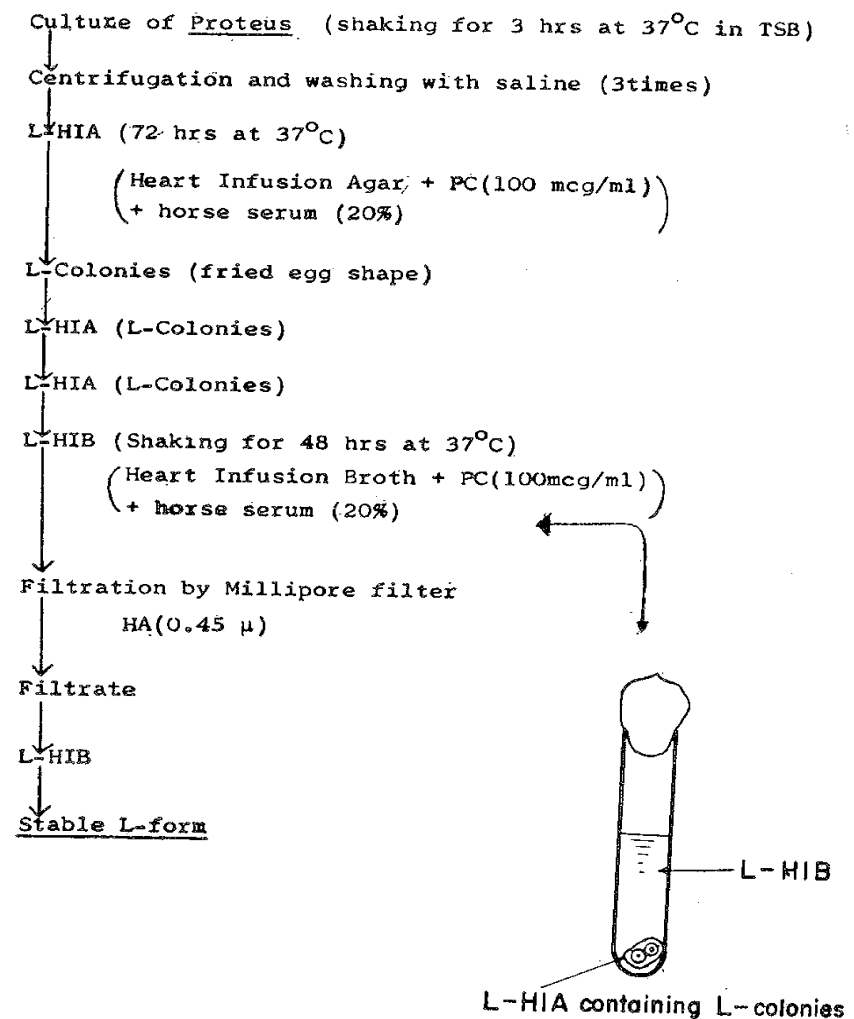




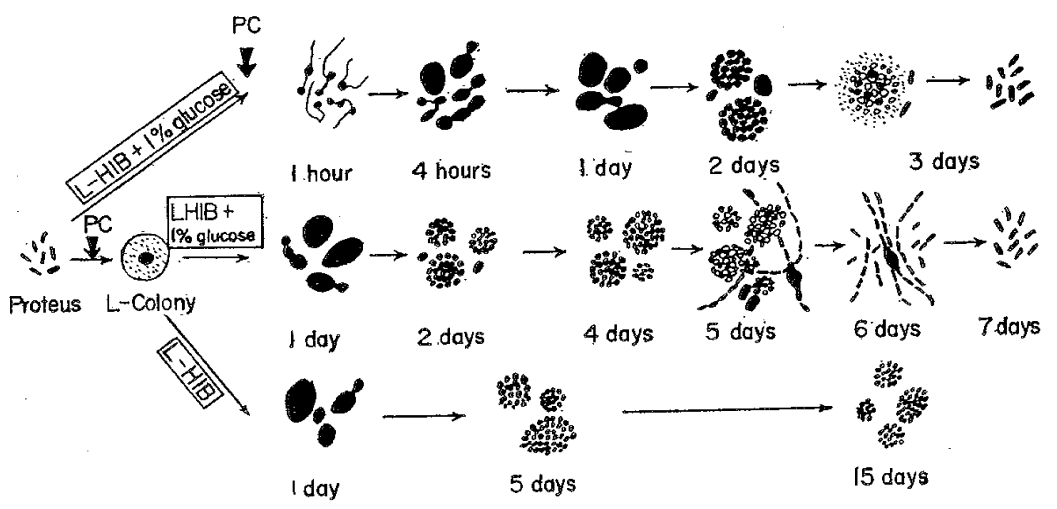

図 2 Transformation and reversion of Proteus mirabilis

ですりつぶすか，まるい社 millipore filter HA $(0.45 \mu)$ 在通すことによつて，すりつぶさないものよりコロニー 形成単位（CFU) が大になることから，この large body は比較的 fragile なものであつて, large body を形づく つている小顆粒が、いわば minimum reproductive form であると考えられる。

次に L-form の classic form (bacteria) 一の復帰 (reversion) である. stable L-form (L-colony) glucose （1％）を含む L-HIB で培養すると，約 4 日目までは 前述のごとくL-form のまま維持されるが，5日目あた りから，小顆粒の一部が著しく染色性（メチレン青，ギ ームザ染色共に）を失い，小顆粒の集団から七モ状の形 態が現われる。更に小顆粒加ら成る large body 法，も はや見られなくなり，視野一快いにヒモ状の Proteus 菌 が認められる. 次の 24 時間後には，この filamentous Proteus 治んどみられず， bacterial form に先祖返り する(図 2 中段)。

一方，初め L-HIA で L-colony を作ることなく， Proteus 菌を直接液体培地 (L-HIB) に培養した場合は
Proteus 菌任数時間で姿を消すがその後, 濁度の上昇 (O.D. in $540 \mathrm{~m} \mu$ ) がわずかに見られる程度で L-form の発育注非常に悪々．他方，この液体培地 (L-HIB) 飞 glucose を1\%に加えた培地に直接培養した場合は，接 種 1 時聞後には，すでに Proteus 菌の classic form 汢 1 個も譛められず，図 2 の上段の最初に見られる様に， 所々膨大した部分を持つ非常に細い䒺くずの様な形態が 見られる。4時閒後には既述の large body，更に2 日 目に注その large body の中に小顆粒構造が胃られるよ

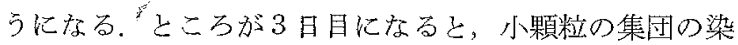
色性が著しく悪くなり，その質から親の Proteus 菌が出 現し完全に先祖に返る。ちなみに，もとの Proteus 菌 と，L-form から先祖返りした Proteus 菌とでは，遊走 性, ゼラチン液化能, $\mathrm{H}_{2} \mathrm{~S}$ 産生能, 抗生物質感受性に於 て差がなかつた。

更にこの実験を通じてわれわれがつかんだ事実は LHIA という培地は正しく mycoplasma 培地（表11）で あつて，したがうて L-form は培養してみると Chanock の完全培地によく增殖寸ること，ただし mycoplasma に 䘚 11 Induction and Growth of L-form

\begin{tabular}{|c|c|c|c|c|c|}
\hline \multicolumn{2}{|c|}{ Medium } & \multirow{2}{*}{$\frac{\text { L-form }}{-}$} & \multicolumn{2}{|c|}{$\begin{array}{l}P . \text { mirabilis } \\
\text { Classic } \rightarrow \text { L-form }\end{array}$} & \multirow{2}{*}{$\frac{\mid \begin{array}{c}\text { Mycoplasma } \\
\text { pulmonis mA }\end{array}}{-}$} \\
\hline $\mathrm{HIA}^{1}{ }^{1}$ & & & + & - & \\
\hline L-HIA ${ }^{23}$ & & + & - & + & + \\
\hline \multirow{3}{*}{$\mathrm{HIA}+\mathrm{TA}^{33}$} & $(100 \mathrm{mcg} / \mathrm{ml})$ & - & + & - & - \\
\hline & $(500$ & - & + & - & - \\
\hline & $(1500$ & - & - & - & - \\
\hline \multirow[t]{3}{*}{$\mathrm{L}-\mathrm{HIA}+\mathrm{TA}$} & $(100 \mathrm{mcg} / \mathrm{ml})$ & + & - & + & + \\
\hline & $(500$ & + & - & + & + \\
\hline & $(1500$ & - & - & - & - \\
\hline PPLO agar ( $\mathrm{T}$ & $\mathrm{A} 500 \mathrm{mcg} / \mathrm{ml})$ & + & + & - & + \\
\hline
\end{tabular}

1) HIA : Heart infusion agar

2) L-HIA : HIA +PC $(100 \mathrm{mcg} / \mathrm{ml})+$ horse serum $(20 \%)$

3) TA: Thallium acetate 
比ベコロニーの出現が早く（1〜2日）またそのコロニ 一の直径む mycoplasmaに比べ大きく，更にコロニーは 常に淡黄褐色を呈していることであつた。したがつて夹 験的に誘導した Proteus L-form に関する限り mycoplasma とは形態学的に“区別できる”ということであ つたが，その後臨床材料から L-form の分離の作業が始 まるにつれてこの事実沙またくず机去るのである。

な晾醋酸タりウムに注 L-form を誘導する作用はない といわれている(Morton, H.E., \& Lecce, J.G., 1913) 更に L-form 誘導培地 (L-HIA) に少なくとも500 $\mathrm{mcg} /$ $\mathrm{ml}$ の醋酸タリウムを加えてもその培地の上で L-form の誘導は阻止されない（表 11 中央コラム）。結果として この thallium acetate marker に関する限り L-form と mycoplasma は異ならない（精しい表の説明は省略する が向つて左と向つて右のコラムの十又は一の一致)。

表 12 Markers for Differentiation of Various Organisms

\begin{tabular}{l|c|c|c|c}
\hline & Bacteria & L-Form & PPLO & Protozoa \\
\hline Penicillin & + & - & - & - \\
Neocarzinostatin & - & + & + & + \\
Cycloheximide & - & - & - & +
\end{tabular}

第 12 表に示す様にペニシリンが効かず，高分子のDNA 合成阻害剂 (Neocarzinostatin) が有效であり，しかも cycloheximide が効かないという意味で生物学的にこの ふたつは非常に相似した微生物である。

\section{6) まとめ}

以上われわれ娔体的比 mycoplasma 公分離する方法 を知り，上-form 誘導する方法を知り，その後患者(特 に原路感染）加ら多くの L-form の分離し得ることを知 つた (未発表) 患者加分離される L-form はその増殖 速度の扟ていと，コロニ一の小さいこと，まさに my． coplasma で岁り， in vitro で誘導した L-form とはか なり慰じを異にする。

すると臨床検盖の問題点としては（1)今後末知の病原 体の分離に際しては Chanock は完全培地を用いるとい う操作が要求されること，(2)そこで分離されるものは mycoplasma 丸 L-form で文り，前者は血清学的に判別 できるが後者の判別を如何に行ならかがな沶問題として 残されること(しかし stable L-form でもグルコース 加液体培地中で先祖返りし易いという性翼があるから常 識的にはL-formで岕ことの判定は可能である)。(3) そ してこれ等 “世界最少の anabolism \& catobolismも備 えた微生物の存在”が如何なる病原的意義有するか,
その病原的意義を邀求する必要があることが結論として 残された.

別に生物学的観点からは mycoplasma と L-form, 殊 にstable L-form は現世に於てちがつた 微生物か同に゙微 生物かが不明の京残されている（表12）。Smith(1964) の綜説以後特にこれといつた解決策の呈示もない，共に 培養に時閒を要することがこれ等研究の進展を妨げてい る様に思われる。

附記：M. pneumoniae の補結抗原の精製法とそれに よる急性呼吸器感染症の病因分析にも講演では子れたが ここには省略した。沼踦らと共に原著として発表の予 定.

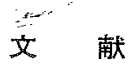

1) Baernstein, H. D. \& J. J. Quilligan: Cultivation of mycoplasma pneumoniae. J. Bact. 86, 339 1963. -2) Godzenski, C. W. et. al. : L-phase growth induction as a general charteristic of antibiotic-bacterial interaction in the presence of serum. Antimicrobial agents \& chemotherapy(1962), p. 843. -3) Gutman, L. T. et al. : Bacterial L-forms in relapsing urinary-tract infection. Lancet 1, 464, 1967. - 4) Hayflick, L. \& Chanock. R. M. : Mycoplasma species of man. Bact. Rev. 29, 186, 1965. 一5) 本間, 石田; 癌と PPLO (Mycoplasma)，医学の㚣沛多 67 (4)，昭43,1,27. 揭载予定（文部省特別研究“湂”研究報告と乙て印刷 于孙). -6) Klieneber-Nobel, E. et al. : Pleuropneumoia-like organisms as agents of human and animal diseases. (Symposium X). Recent Progress in Microbiology, VIII, p. 518, Montreal, 1962. 7) Macpherson, I. \& Russell, W.: Transformations in hamster cells mediated by mycoplasmas. Nature 210, 1343, 1966. - 8) Morton. H. E. \& Lecce, J. G. : Selective action of thallium acetate and crystal violet for PPLO of human origin. J. Bact. 66, 646, 1963. -9) Mufson, M. A. et al. : Exudative pharyngitis following experimental $\mathrm{My}$ coplasma hominis type 1 infection. JAMA 192, 1146，1965. -10) 二踏堂 他：マウス気管支より 分離されたマイコプラズマの性状（第1報），日細誌 21, 13, 1966. -11) Purcell, R. H. \& Chanock R. M. : Role of mycoplasmas in human respiratory disease. Medical Clinics of North America, 51, 791, 1967, -12) Stanbridge, E. \& L. Hayflick: Growth inhibition test for identification of Mycoplasma Species utilizing dried antiserum impregnatied paper discs. J. Bacteriol. 93, 1392. 1967. -13) Smith,P. F. : Comparative physiology of pleuropneumonia like and L-type organisms. Bact. Rev, 28, 97, 1964. 